\title{
Oh what a beautiful morning! The time of day effect on the tone and market impact of conference calls
}

Citation for published version (APA):

Chen, J., Demers, E., \& Lev, B. (2013). Oh what a beautiful morning! The time of day effect on the tone and market impact of conference calls. Maastricht University, Graduate School of Business and Economics. GSBE Research Memoranda No. 038 https://doi.org/10.26481/umagsb.2013038

Document status and date:

Published: 01/01/2013

DOI:

10.26481/umagsb.2013038

Document Version:

Publisher's PDF, also known as Version of record

\section{Please check the document version of this publication:}

- A submitted manuscript is the version of the article upon submission and before peer-review. There can be important differences between the submitted version and the official published version of record.

People interested in the research are advised to contact the author for the final version of the publication, or visit the DOI to the publisher's website.

- The final author version and the galley proof are versions of the publication after peer review.

- The final published version features the final layout of the paper including the volume, issue and page numbers.

Link to publication

\footnotetext{
General rights rights.

- You may freely distribute the URL identifying the publication in the public portal. please follow below link for the End User Agreement:

www.umlib.nl/taverne-license

Take down policy

If you believe that this document breaches copyright please contact us at:

repository@maastrichtuniversity.nl

providing details and we will investigate your claim.
}

Copyright and moral rights for the publications made accessible in the public portal are retained by the authors and/or other copyright owners and it is a condition of accessing publications that users recognise and abide by the legal requirements associated with these

- Users may download and print one copy of any publication from the public portal for the purpose of private study or research.

- You may not further distribute the material or use it for any profit-making activity or commercial gain

If the publication is distributed under the terms of Article $25 \mathrm{fa}$ of the Dutch Copyright Act, indicated by the "Taverne" license above, 
Jing Chen, Elizabeth Demers, Baruch Lev

Oh what a beautiful morning! The time of day effect on the tone and market impact of conference calls

$\mathrm{RM} / 13 / 038$

\section{GSBE}

Maastricht University School of Business and Economics

Graduate School of Business and Economics

P.O Box 616

NL-6200 MD Maastricht

The Netherlands 


\title{
Oh What a Beautiful Morning!
}

\section{The Time of Day Effect on the Tone and Market Impact of Conference Calls}

\author{
Jing Chen* \\ Elizabeth Demers ${ }^{\epsilon}$
}

Baruch Lev ${ }^{\pi}$

May 2013

\footnotetext{
* Stern School of Business, New York University, jchen2@stern.nyu.edu

${ }^{€}$ Ross School of Business, University of Michigan and the Darden School, University of Virginia, demerse@darden.virginia.edu (corresponding author)

${ }^{\pi}$ Stern School of Business, New York University, blev@stern.nyu.edu

We thank Greg Miller, the University of Michigan PhD students, and seminar participants at the National University of Singapore and Yale University for helpful comments and suggestions.
} 


\title{
Oh What a Beautiful Morning! \\ The Time of Day Effect on the Tone and Market Impact of Conference Calls
}

\begin{abstract}
Using textual analysis software, we examine whether and how the tone of the question and answer ("Q\&A") portion of earnings-related conference calls varies with the time of day. We find that the tone of the conversations between analysts and managers becomes significantly more negative as the day wears off. This continuous, hour-by-hour change is likely the result of mental and physical fatigue gradually and imperceptibly setting in. The same pattern holds for textual uncertainty, increasing as the day wears off, the conversational tone is more wavering and less resolute. We document that conversational tone has economic consequences; more negatively toned conversations are associated with more negative abnormal stock returns during the call period and immediately thereafter. Notwithstanding the negativity associated with later day calls, firms exhibit significant "stickiness" in their choice of call time; having initiated the earnings conference call in the afternoon in the prior quarter is the most significant determinant of their doing so in the current quarter, dominating the sign of the earnings news and alternative measures of the firm's need for equity capital. Analysis of post-call (50 days) returns indicates that there is an initial negative overreaction to bad news earnings information and, incrementally, to calls initiated in the afternoon, that eventually reverses. In contrast, the negative impact of tone deterioration on stock returns, documented here, does not reverse. To the best of our knowledge, this is the first study to document the effects of human physiological and mental factors on corporate communications with investors.
\end{abstract}




\section{Introduction}

Conference calls have become the major channel of corporate communications to outside stakeholders (Frankel, Johnson \& Skinner (1999); Bushee, Matsumoto \& Miller (2003); Skinner (2003)). Earnings related conference calls are typically conducted within a few hours to a day following the quarterly earnings release, and consist of a managerial presentation (that generally reiterates the main content of the earnings press release), followed by a question-and-answer (Q\&A) session with analysts and investors. As a result of the analyst-management interaction, the Q\&A portion of the call elicits significant incremental information over the earnings announcement and managerial presentation (Matsumoto, Pronk \& Roelofsen (2011)). Various aspects of conference calls have been examined by researchers, such as the impact of the call on stock prices and volumes, or the effect of the call's tone and other characteristics on prices and analyst recommendations. In the current study, we examine a new dimension of conference calls: whether and how the tone of call conversation and its consequences varies with the time of day, reflecting the mood and the levels of mental and physical state of call participants. Unlike corporate press releases and the text of mandatory filings that have been examined in prior financial linguistics studies, the Q\&A portion of the conference call is not scripted by lawyers and communications experts, and is more likely to involve natural, less inhibited use of language. We, therefore, expect that our linguistic measures will capture the spontaneous tone and nuance of the communications between parties to the call.

Using multiple proxies for two linguistic dimensions that we term negativity and textual uncertainty, we find that the time of day at which the call was initiated (our proxy for call participant mental and physiological state), impacts in a remarkably systematic manner these tonal aspects of manager-analyst interchanges. Specifically, as the day wears off, participants' 
tone gets increasingly negative and uncertain (wavering) - see Figures 1 and 2. This changing conversational tone has real economic consequences: our measures of linguistic tone are associated with the firm's intraday call period stock returns and return volatilities, as well as the 50-day post-call drift returns. To the best of our knowledge, ours is the first study that relates the tonal aspects of financial communications to the time of day.

It is well-known that physical and mental fatigue cause irritability and a decline in executive function. ${ }^{1}$ Both the passage of time (without eating) and the performance of taxing mental activities deplete the body's glucose reserves, which in turn reduces a person's capacity for selfcontrol (M. T. Gailliot \& R. F. Baumeister (2007); Coates (2012)). Mood and executive function can be restored, inter alia, by a short rest, positive affect, or an increase in glucose levels in the body. $^{2}$ Drawing on this neuroscientific and psychological research, we examine whether human physiological and mental factors impact the tone of discussions between managers and some of the firm's most important constituents - financial analysts and large investors - by using the time of day at which conference calls begin as a proxy for call participant state of executive function. Our reliance on this proxy is premised upon the assumption that managers' and other call participants' fatigue is likely to be increasing throughout the day as the effects of mental exertion and declining glucose levels affect the organism, with a partial recovery around mid-day, when most individuals restore themselves with food and a respite from intensive mental activity. This

\footnotetext{
${ }^{1}$ Executive function is an umbrella term for cognitive processes such as planning, working memory, attention, problem solving, verbal reasoning, inhibition, mental flexibility, multi-tasking, and initiation and monitoring of actions.

${ }^{2}$ It has been extensively documented that the repetition of even simple decision-type tasks reduces an individual's executive function, but that this function can be subsequently restored with rest or positive affect (Baumeister (2002)), or by increasing glucose levels in the body (M. Gailliot \& R. Baumeister (2007)).
} 
assumption is supported, for example, by a similarly documented pattern of declining judicial function throughout the morning, improvement after the mid-day lunch break, followed by a repeated decline in function throughout the afternoon, in the context of judicial rulings involving parole decisions (Danziger, Levav \& Avnaim-Pesso (2011)).

In order to investigate the impact of the time of day on the tone of conference calls' Q\&As, we apply two widely used linguistic algorithms, Diction 6.0 and the Loughran \& McDonald (2011) dictionaries, to the transcripts of the Q\&A sections of more than 26,000 corporate quarterly earnings-related conference calls conducted during 2001-2007. Each of the linguistic algorithms makes reference to a dictionary list of words associated with a particular underlying tone construct (e.g., negativity or certainty) and provides a linguistic score that is based upon the proportion of words in the examined text associated with that tone construct. We measure tone negativity in multiple ways, and find consistent results across tone proxies that the time of day, which is presumed to reflect participants' physical and mental state, systematically influences the negativity of call participants' dialogue. Specifically, the tone of conference call Q\&A sessions becomes increasingly negative as the morning progresses, but then the decline in mood abates and even slightly improves around mid-day, when call participants are likely to have restored themselves mentally and physically with food and a short pause in the intensity of their cerebral activity. After the mid-day break, the pattern of increasing negativity resumes throughout the afternoon trading hours. Subsequent to the mental relief brought by the exchange closing bell, which we interpret to be a positive affect in the stressful day of call participants, particularly analysts and investors, the tone of conversations becomes more positive.

Overall, the tone of Q\&A sessions of conference calls that originate later in the day is significantly more negative, irritable and combative than that of calls originating in the earlier 
morning hours, even after controlling for other determinants of call tone, such as industry factors, measures of corporate financial distress and growth opportunities, and particularly the earnings message itself (i.e., the earnings surprise and whether the firm reported a loss for the quarter). These surprising findings offer a clear operational message to managers, namely that mornings may be a "beautiful" time to host calls with the firm's important constituents, whereas afternoon interactions have adverse consequences on stakeholder relations and share prices. ${ }^{3}$

Our second dimension of tone, measured by Diction's certainty metric, captures the extent to which language is resolute or inflexible. We find that the textual uncertainty of the Q\&A session follows a similar pattern to that of tone negativity, increasing throughout the morning, abating around the mid-day break, and increasing again throughout the afternoon until the end of stock trading. The evidence thus indicates that the tone of the Q\&A discussions becomes more flexible, wavering and less resolute as physical and mental fatigue set in.

We then investigate whether the observed changing tone dimensions have economic consequences by relating the tone measures to various intraday market measures of stock returns and their volatilities. Consistent with the findings of Price, Doran, Peterson, \& Bliss (2012), we document that measures of conference call tone are indeed associated with intraday returns: conference call firms' returns for the 5-hour interval starting with the call's initiation are positively associated with the tone of discussions - the more negative the tone, the lower the

\footnotetext{
${ }^{3}$ Surprisingly, a substantial number of large firms with savvy investor relations knowledge, such as CitiGroup, J.P. Morgan Chase, Time Warner, ExxonMobile, IBM, Pfizer, Coca Cola, and Goodyear, conducted their earnings calls in the afternoon.
} 
abnormal returns. We extend the previous results by documenting that trade volume and price volatility are associated with textual uncertainty.

We also investigate the determinants of the firm's decision to initiate calls in the afternoon, given the apparent costs of doing so: contentious, argumentative communications with key stakeholders, leading to more negative abnormal returns. Particularly intriguing is the "stickiness" in firms' choice of afternoon call initiation, as the holding of an afternoon call in the previous quarter is the most important determinant of the call being initiated in the afternoon of the current quarter. We document that firms reporting "bad news" (i.e., a loss or missing analyst consensus estimates of earnings), as well as high-tech and smaller firms, are more likely to hold their calls in the afternoon. The latter result may be explained by the fact that in certain days following a calendar quarter there is bunching of earnings announcements and conference calls, and smaller firms, followed by fewer analysts, may be "crowded out" of the prime early hours of the day. Surprisingly, once the prior quarter's afternoon call choice has been controlled for, neither missing analyst earnings expectations nor high-tech industry membership affect the likelihood of holding the call in the afternoon.

Our final analyses document the associations between post-call abnormal returns, call tone, and the decision to initiate the call in the afternoon. We find that afternoon calls are followed by significantly more negative abnormal returns than morning calls over the first 15 trading days after the close of the 5-hour announcement window, but that this short-term negative returns drift reverses before the next quarter's earnings are released. Both morning and afternoon "bad news" calls experience a negative drift followed by returns reversal, however the pattern is significantly accentuated for afternoon calls, even after controlling for the magnitude of the negative earnings 
surprise. Notably, the initial negative price response to negative conversation tone, which is also partly driven by the timing of the call, does not reverse.

We acknowledge that our study is subject to the limitation that, while we conjecture the state of "executive function" (mental and physical fatigue) is responsible for our documented systematic relation between time of day and conference call tone, we don't prove it directly. That is, we don't subject call participants to physiological tests aimed at establishing their mental and physical state. In our large sample empirical archival setting, we are limited to providing a likely explanation for our findings, rather than to proving the physiological effects directly which can only be done on a very small sample in the laboratory. ${ }^{4}$

Our study relates to several strands of financial and accounting research, including those that examine the intraday timing of corporate communications, the use and impact of conference calls as a communication device, and the application of textual analysis algorithms to financial communications. We contribute to these areas by focusing on the impact of the time of day on the tone of executive-analyst discussions, and documenting its stock return and volume consequences. Our study has important practical and methodological implications. For corporate executives and capital market participants, our findings suggest that the time of day at which a conference call, and likely other corporate communications, are initiated should be carefully chosen, since it significantly impacts the tone of discussions, and that this tone, in turn, has an

\footnotetext{
${ }^{4}$ Relatedly, a commenter on our study questioned whether executives, who are obviously well aware of the importance of quarterly conference calls, will allow themselves to be subject to mental and physical fatigue in the afternoon. Our answer at this stage is two-fold. First, we believe that most executives are not aware of the time-ofday effect that we are the first to document in the current study. After all, the nature of research is that it reveals new things. Second, unlike an exerting physical exercise, such as running, the mental and physical changes documented here are likely subtle and subconscious, and executives and analysts are unaware of them.
} 
immediate announcement period as well as a continuing drift impact on the firm's stock returns. For accounting and finance researchers, our findings indicate that the intra-day timing of conference calls is an important variable in the investigation of the calls' attributes and consequences.

The remainder of the paper is organized as follows. Section 2 discusses prior related literature and presents our hypotheses. Section 3 describes our sample, data sources and variable measurements. Section 4 presents univariate evidence and regression results related to our hypotheses of interest, while Section 5 summarizes and concludes the study.

\section{Literature Review and Hypotheses Generation}

\subsection{Prior Related Literature}

Our study relates to three primary strands of the literature: i) the timing of intraday corporate communications; ii) the use and impact of corporate conference calls as a communication device; and iii) the application of linguistic algorithms to financial communications. Prior studies have documented the propensity for corporate good news to be released during market hours and bad news to be disclosed after the close of trading (Patell \& Wolfson (1982); Francis, Pagach \& Stephan (1992)). Subsequently, Gennotte \& Trueman (1996) advanced a theory to explain why this behavior is rational under certain reasonable conditions. Survey evidence also suggests that managers tend to change the date, and to a lesser extent the timing during the day, of their earnings announcements depending upon the sign and magnitude of the earnings surprise, and that the size of the firm and the exchange upon which the firm's stock is traded impact these strategic maneuvers (Chen \& Mohan (1994)). 
Frankel et al. (1999) establish that conference calls convey material information to the market, as evidenced by the unusual stock return volatility and trading volume during the period of the call. Matsumoto et al. (2011) report that the Q\&A portion of calls is more informative than the preceding managerial presentation, and that this greater information content is increasing in analyst following and when firm performance is poor. Bushee, Matsumoto \& Miller (2004) document that conference call timing tends to be "sticky", with $87 \%$ of firms in their pre-Regulation Fair Disclosure (Reg FD) sample period either always hosting calls during trading hours or always hosting calls after trading hours, and approximately $76 \%$ (85\%) of firms with a pre-Reg FD policy of hosting their calls during (after) trading hours continue to do so in the post-Reg FD period.

Our study also relates to the rapidly expanding stream of research that uses textual analysis algorithms in financial contexts to examine the information content of linguistic tone for contemporaneous and future stock returns, return volatilities, and future earnings or cash flows and their uncertainties. Prior financial linguistic studies have established the share price relevance of textual content (or linguistic tone) in the context of mandatory filings, such as earnings announcements (Davis, Piger \& Sedor (2012); Demers \& Vega (2012)), restatement announcements (Mangen \& Durnev (2010)), IPO prospectuses (Balakrishnan \& Bartov (2011)), and MD\&A and other elements of the 10K reports (Li (2010); Loughran \& McDonald (2011)). Baginski, Demers, Wang, \& Yu (2012) and Demers \& Yu (2013) document that linguistic content is also price relevant in the less structured context of voluntarily issued management forecast announcements. The evidence presented by Tetlock, Saar-Tsechansky \& Macskassy (2008) in the context of the media, and Demers \& Vega (2012) for management-issued press releases, also supports the notion that investor response to linguistic tone is rational in the sense 
that tone incrementally predicts the firm's future cash flows and their uncertainties. Closely related to our study, Price et al. (2012) find that conference call linguistic tone is a significant predictor of abnormal returns and trading volume, and that tone dominates the size of the earnings surprise over the 60 trading days following the call. Schoenfeld (2012) documents that call tone predicts analyst buy recommendations as well as the likelihood that the firm will meet or beat analyst expectations for the subsequent quarter. The tone of the Q\&A portion of the call has incremental explanatory power for the post-earnings announcement drift, and this significance is mainly concentrated in firms that do not pay dividends (a proxy for greater investor cash flow uncertainty). Our focus - the time-of-day impact on call tone and in turn on stock prices and volatilities — has not been previously examined.

\subsection{Hypotheses Development}

Using the time of day of the conference call's initiation as our proxy for the physical and mental state of call participants leads us to investigate the following hypotheses:

H1: The negativity of the Q\&A portion of conference calls increases with the time of day.

H2: The textual uncertainty of conference call Q\&As increases with the time of day.

In order to document that the tone of conference calls has economic significance, we test the following hypotheses:

H3: The negativity of the conference call Q\&A discussions is associated with decreasing abnormal intraday stock returns.

H4A: The textual uncertainty of the conference call Q\&A discussions is associated with abnormal intraday trading volumes. 
H4B: The textual uncertainty of the conference call Q\&A discussions is associated with abnormal intraday stock return volatilities.

\section{Sample, Data, and Descriptive Statistics}

\subsection{Sample Determination}

We obtain conference call transcripts, spanning the period of January 2001 to June 2007, from Thomson StreetEvents, a division of the Thomson Reuters news service and database vendor. We restrict our sample to transcripts for which we are able to extract a reliable call start time, location time zone and firm ticker information. We further restrict the sample to transcripts in which the Q\&A portion of the call exceeds 100 words, and to firms that are publicly-traded, headquartered in the United States, that can be matched with the CRSP/Compustat databases, and that have non-negative common book value of equity. We focus on conference calls that follow earnings announcements, which we define as falling into a window of $(0,2)$ days relative to the $t=0$ earnings announcement day. To assure time uniformity, for our primary tests, we focus on calls that are initiated in Eastern or Central Time locations, which are initiated during the window of 08:00 to 16:59 Eastern Time. The imposition of these constraints yields a sample of 26,585 calls initiated by 2,113 distinct firms. In separate analyses, we also include calls initiated in Mountain and Pacific time zone locations. Details related to the impact of each of the sample inclusion criteria on the final determination of the sample are summarized in Table 1.

\subsection{Data Sources}

We obtain accounting data from the Compustat database, daily stock price and volume data from CRSP, and intraday price and volume data from the Trades and Quotes (TAQ) database. 
Data related to analysts (earnings estimates, earnings surprises, and analyst following) are derived from IBES.

\subsection{Measuring the Textual Content Variables}

We focus on the Q\&A portion of the conference call since, unlike the opening management presentation, this part of the communication is natural and not carefully scripted in advance by communications experts and the firm's legal advisors. Thus, linguistic measures derived from the Q\&A section capture the spontaneous tone of discussion between call participants, which in turn we hypothesize to vary in accordance with human mental and physiological functions. Using two alternative linguistic algorithms, Diction 6.0 and the Loughran \& McDonald (2011) ("L\&M") dictionaries, we extract textual content variables from the Q\&A transcripts.

Diction 6.0 is a well-established text-analysis program which provides measures for 35 different linguistic attributes that can be concatenated to represent five linguistic master variables (Hart \& Carroll (2010)): For example, Diction's "Optimism" is a master variable that is calculated as a function of 6 other linguistic scores, as follows: (praise + satisfaction + inspiration) - (blame + hardship + denial). Prior finance and accounting studies suggest, however, that generic linguistic algorithms such as Diction may yield noisy measures of "positive" and "negative" linguistic tone in the context of financially-oriented text messages (e.g., Loughran \& McDonald (2011); Demers \& Vega (2012)). Accordingly, we also use the L\&M finance-oriented dictionaries, for capturing the "positivity" and "negativity" in our conference call transcripts. Both algorithms use a series of dictionaries, or word lists related to a 
particular underlying construct (e.g., positivity, negativity, uncertainty, tenacity, praise, blame, aggression) to extract a score which is based upon the number of incidences of words from each dictionary that are cited in the examined text passage. ${ }^{5}$ Although the dictionaries underlying Diction's five master variables are typically larger than those of L\&M's linguistic scores, they are not specifically tailored to financial textual passages. Our approach of using both algorithms ensures that the results are robust across alternative empirical measures of tone constructs.

We use L\&M's financial positivity, negativity, and uncertainty scores, as well as their analogues from Diction: optimism, pessimism, and linguistic certainty. ${ }^{6}$ To standardize the scores cross-sectionally, we first extract the raw scores (i.e., a dictionary count) for each linguistic construct using Diction and the L\&M dictionaries, divide each of the raw scores by the total number of words in the Q\&A portion of the call, and then multiply this percentage by 100 . Following the prior literature, we also take the difference between negativity and positivity (pessimism and optimism), and refer to these measures as L\&M net negativity (Diction: net pessimism). ${ }^{7}$ Finally, we redefine the Diction measure of certainty to treat numerical terms as

\footnotetext{
${ }^{5}$ Words that L\&M include in their "negativity" dictionary include, for example: abandon, accident, aggravate, bankrupt, bottleneck, challenge, default, and so forth. The full set of L\&M word lists are available here: http://nd.edu/ mcdonald/Word_Lists.html.

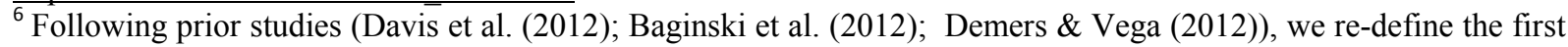
three components of Diction's optimism score (praise + satisfaction + inspiration) to be "optimism" and label the second set of three components (blame + hardship + denial) as "pessimism."

${ }^{7}$ Technically speaking, the prior literature takes the difference between positivity and negativity (optimism and pessimism) and refers to this as net positivity (net optimism). Because the tone of our calls is, on average, net negative, for tractability in the text we have simply inverted the subtraction and renamed the variable accordingly.
} 
additive rather than subtracting them from the certainty score, following the reasoning suggested by Demers \& Vega (2012). ${ }^{8}$

\subsection{Descriptive Statistics}

Table 2 presents descriptive statistics for the firms included in our sample. These firms tend to be substantially larger (measured by either total assets or sales), more profitable (based upon incidence of loss quarters), more likely to meet-or-beat analyst estimates, and have a larger analyst following than the Compustat-IBES universe. However, the sample firms are not significantly different than other firms in terms of growth prospects and unrecorded intangibles, as captured by the median market-to-book ratio.

Table 3 provides descriptive data related to conference calls initiated in Eastern and Central time zones. Panel A shows that, on average, individual firms appear almost 13 times in the sample, with a minimum of firms appearing only once (i.e., we have only one conference call transcript for these firms) and a maximum of a firm with 41 conference calls. The top results in Panel B1 show that, for firms with more than one observation in our sample, 33\% consistently hold their conference call at the same time of day, while $67 \%$ of firms vary the timing of calls. In the lower set of results in Panel B1, we find that $66 \%$ of firms "typically" hold their calls at the same hour of the day, where "typically" is defined as $75 \%$ of the time. ${ }^{9}$ Panel B2 provides a transition matrix for firms that we characterize as having a high degree of stickiness (i.e., firms

\footnotetext{
${ }^{8}$ In other words, we redefine certainty to be [tenacity + leveling + collectives + insistence + numerical terms $]-$ [ambivalence + self-reference + variety].

${ }^{9}$ In untabulated results we also find that, $60 \%$ of firms "typically" hold their conference calls at exactly the same hour of the day, where "typically" is defined as $80 \%$ of time.
} 
that hold their conference calls at precisely the same time with at least $75 \%$ frequency). As shown, only $7.56 \%$ of "bad news" firms (i.e., those that either miss analyst estimates or report a loss) change the time of their conference calls, whereas $6.93 \%$ of "good news" firms change the time of their call relative to the prior quarter. ${ }^{10}$ Thus, the good versus bad news flavor of the earnings news does not seem to be an important factor in "sticky" firms' decisions to change the time of their calls from one quarter to the next.

We also consider the firm's choice of a within-versus-outside of market hours calls. Panel C shows that $65 \%$ of firms with more than one call in our dataset consistently hold their calls either within or outside of market hours, with $41 \%$ of firms holding their conference calls exclusively during market hours, and $24 \%$ of firms holding their calls exclusively off market hours. The remaining $35 \%$ of firms do not exhibit consistent choices between within versus outside of market hours for their conference call start times. Panel D1 shows that, for the 859 firms that only hold their calls within market hours, $65 \%$ hold them only in the morning while $6 \%$ hold them exclusively in the afternoon, and the remaining $29 \%$ of firms exhibit no stickiness with respect to timing within trading hours. Panel D2 documents that, for firms that hold their calls only outside of market hours, $75 \%$ exhibit stickiness with an almost equal proportion of companies holding their calls only before the open (37\%) versus only after the close of trade $(38 \%)$.

Panel E investigates stickiness by hour of the day. As shown, 15\% of "sticky" firms (i.e., those hosting calls only in morning or only in afternoon) always host their calls during the same

\footnotetext{
${ }^{10}$ Results are nearly identical when "bad news" is defined to include only firms that miss analyst estimates.
} 
hour before 10 a.m., $38 \%$ always start their calls during the hours of 10 or 11 a.m., and $18 \%$ of companies start their calls after 12:59 p.m. Finally, Panels F1 and F2 show that the timing of calls for firms that meet or beat analyst expectations is quite similarly distributed to that of firms that report bad news (i.e., miss analyst estimates), with $51 \%$ and $53 \%$, respectively, initiating their calls during morning market hours, $8 \%$ and $10 \%$ initiating during afternoon market hours, $23 \%$ and $19 \%$ initiating before the opening bell, and $18 \%$ and $18 \%$ holding calls after the close.

Overall, the evidence presented in Table 3 indicates that there is a fairly high degree of "stickiness" in the timing of conference calls, and that the earnings message doesn't materially affect this timing, as both bad news and meet-or-beat firms generally time the initiation of their calls in a similar manner with respect to market hours.

\section{Empirical Results}

\subsection{Linguistic Sentiment Varying By Time of Day: Univariate Evidence}

Table 4 and Figures 1 and 2 present the mean levels of each linguistic sentiment measure classified by the hour of the day (stated in Eastern Time) during which the conference call began. We focus on the results in Panel A of Table 4, which are for calls originating in the Eastern and Central time zones, since the call participants' body clocks in this sample are likely to be aligned with the Eastern time zone hour in which our data is reported. Panel B reports the same statistics for firms in all time zones, for which the patterns described below are broadly similar.

As shown in Panel A of Table 4, the sentiment of the Q\&A portion of earnings conference calls varies in a remarkably systematic way by time of day in the manner predicted, with the tone becoming increasingly negative from the start of the day to the mid-day break (LM Negativity $=0.928$ at $8: 00-8: 59$, increasing to 1.037 at $12: 00-12: 59$, the difference is statistically significant at the 0.01 level). The tone negativity improves slightly after the break (down to 1.017 
in 13:00-13:59), and then deteriorates again as the afternoon unfolds. The negativity level reaches its highest level of the day, 1.07, in the last hour of trading, with an improvement after trade closes (from 1.07 to 1.014). The same pattern is evident for the LM net negativity (negativity minus positivity) measure, which increases monotonically through the 13:00-13:59 hour. Notably, the Diction analogues of LM negativity — pessimism and net pessimism behave almost identically to the LM measures, reaffirming our findings. Note that the tone changes during the day are large. For example, L\&M net negativity is 0.412 for calls originating during the last hour of trading, almost double the net negativity magnitude of 0.225 that prevailed during the hour prior to the market's open. The stress relief from the close of the trading day (after 16:00) seems to serve as a positive affect for call participants, with temperaments improving in the post-trading hours. This is evidenced by negativity (net negativity) getting significantly lower in the first hour after the market closes (16:00-16:59), relative to the tone that prevailed during each of the preceding afternoon hours of trading. Overall, as shown in the right-hand portion of the table, the patterns for the Diction-based measures of pessimism and net pessimism are practically identical to those for L\&M's negativity and net negativity metrics. We stress the extraordinarily systematic behavior of our findings: the predicted tone change occurs for each examined hour. These results are graphically presented in Figures 1 and 2.

Moving from tone negativity to the certainty dimension, Diction's certainty measure (TCertainty) captures language indicating resoluteness, inflexibility, and completeness (Hart \& Carroll (2010)). Prior authors find that the L\&M's measure of uncertainty (TUncertainty) is somewhat less multi-dimensional, typically capturing more limited elements of economic uncertainty than the Diction measure (Demers \& Vega (2012)). Panel A of Table 4 shows that 
L\&M's uncertainty is increasing monotonically through the morning until the hour of 12:0012:59, when it decreases from 0.578 to 0.566 over the 13:00-13:59 hour, followed by an increasing pattern of uncertainty through the afternoon trading. A similar, even stronger, pattern is noted for Diction's TCertainty score, with this measure declining through the morning until (and including) the hour of 12:00-12:59. TCertainty increases after this mid-day break, but then continues to decline monotonically through the close of the market and the hour beyond.

Overall, the descriptive data shown in Table 4 presents a clear and consistent story: the tone of conference calls becomes increasingly negative and less resolute with the decline in mental and physical capacities occurring during the morning, abating temporarily after the mid-day break, and resuming the negativity and uncertainty climb thereafter. Interestingly, the mood of conference call participants improves after the pressures of the trading day have subsided, as the tone of calls during the first hour after the market closes is considerably less negative than the tone of calls during the last several hours of trading. In a remarkable consistency, these results hold across all of the alternative measures capturing linguistic tone (i.e., L\&M's negativity and net negativity, as well as Diction's pessimism and net pessimism). As shown in Panel B of Table 4, when we add to the sample the Mountain and Pacific time zone calls, we obtain almost identical results to the Eastern and Central zone calls in Panel A. ${ }^{11}$

\footnotetext{
${ }^{11}$ When we run the analysis of Table 4 separately for Mountain and Pacific zone calls, we get very similar tone patterns to those reported in Table 4. Note that for this alternative sample we have managers conducting the call at their Pacific time (say, 9:00AM), while for most analysts and investors, based in the East Coast, the time is three hours ahead (say, 12:00PM). We interpret the similarity of the tone pattern for Mountain and Pacific time zone firms to that of the Eastern and Central sample to imply that our findings regarding tone changes during the day are mainly attributed to managers' fatigue and glucose depletion.
} 


\subsection{Linguistic Sentiment Varying By Time of Day: Regression Results}

The univariate evidence presented in the previous section strongly indicates a pattern of increasing negativity and decreasing resoluteness as the day unfolds. Obviously, various factors can contribute to this finding, in addition to the mental and physical fatigue that we conjecture. For example, if conference calls following poor earnings news are mostly held in the afternoon, then a more negative (cantankerous, argumentative) tone can be expected in the afternoon. Or, if small firms, whose financial results are more volatile and unexpected than those of large firms, tend to hold calls in the afternoon, a less resolute afternoon tone can be expected. In the following analyses we therefore control for known factors that may affect our findings. Thus, we formally test the hypothesis that tone is deteriorating with the time of day by regressing the various measures of linguistic sentiment on the variable EST_hour (the hour of the day during which the call was initiated, measured in Eastern time), while controlling for a host of other potential determinants of the tone of the calls' Q\&As. Specifically, we run the following regression (firm and time subscripts suppressed):

Tone $=\alpha+\beta_{1}$ EST_Hour $+\beta_{2}$ SUE $+\beta_{3}$ ToneMgt $+\beta_{4} \log$ TA $+\beta_{5} \log$ Ana $+\beta_{6} \log M B+$ $\beta_{7}$ Loss $+\beta_{8}$ EarnGrowth $1+\beta_{9}$ EarnGrowth $2+\beta_{10}$ EarnGrowth3 $+\beta_{11}$ HighLev + $\beta_{12}$ LowLiquid $+\beta_{13}$ CnsmrXEST_Hour $+\beta_{14}$ MfgXEST_Hour $+\beta_{15}$ HiTecXEST_Hour + $\beta_{16}$ HlthXEST_Hour $+\beta_{17}$ FinlXEST_Hour $+\beta_{18}$ FiscalQtr $+\beta_{19}$ Year $+\varepsilon$,

where the dependent variable, Tone, is alternatively defined as Negativity, NetNegativity, TUncertainty, Pessimism, NetPessimism, and TCertainty, all being the linguistic measures extracted from the Q\&A portion of the call as previously defined. SUE stands for the earnings message - the standardized unexpected earnings (relative to the most recent analysts' consensus estimate) for the quarter to which the earnings conference call relates. ToneMgt is the 
corresponding linguistic measure from the management address portion of the call preceding the Q\&A (a very positive managerial address, for example, may positively affect the tone of the following Q\&A): $\log T A$ is the natural $\log$ of the firm's total assets at the end of the quarter to which the call relates, logAna is the natural log of the number of analysts following the firm for the quarter to which the earnings announcement relates, $\log M B$ is the natural log of the marketto-book ratio, and Loss is an indicator variable set equal to one if the firm has reported a loss for the quarter to which the earnings call relates. EarnGrowth1, EarnGrowth2, and EarnGrowth3 are the subsequently realized changes in quarterly earnings reported in each of quarters $t+1, t+2$, and $t+3$ relative to the same quarter of the prior year, respectively, each scaled by the firm's book value as of the end of period $t$, the quarter to which the earnings conference call relates. These growth variables are aimed at controlling for forward-looking information in the Q\&A. HighLev is an indicator variable set to 1 if the firm's leverage (total assets over the book value of shareholders' equity, at the end of the quarter to which the conference call relates) exceeds 2 , and LowLiquid is an indicator variable set to 1 if the firm's current ratio is below 1.0. We thus control for the current quarter's earnings message, realized future earnings changes, firm size, as well as the information environment, financial health, and growth prospects of the call firms. The remaining variables allow the sensitivity of tone to the time of day to vary across industries, by creating indicators set to 1 for the Consumer Goods (Cnsmr), Manufacturing (Mfg), High-Tech (HiTec), Healthcare (Hlth), and Financial (Finl) sectors, respectively, and multiplying each of these by EST_hour. We also include fiscal quarter and year fixed effects. All of the variables are defined in greater detail in the Appendix. The standard errors for all of the regressions reported in this study are clustered by firm. 
The results for the regression depicted by equation (1) for the EST+CST time zone calls initiated from 8:00 to 16:59, alternatively using L\&M and Diction measures of tone as dependent variables, are reported in Table 5. ${ }^{12}$ As shown by the positive and significant EST_hour coefficient, L\&M's negativity and net negativity, and Diction's pessimism and net pessimism (four left columns of Table 5) are all increasing in the time of day, even after controlling for the tone of the preceding management address and other determinants of the tone of conference calls. These results are consistent with the previously reported univariate measures. The combined findings suggest that the tone of the Q\&A portion of earnings-related conference calls is deteriorating as the day unfolds. ${ }^{13}$ With respect to the control variables, the positive coefficients on the respective ToneMgt variables suggests that the Q\&A inherits, in part, the tone that has been set in the management address, while the negative coefficient on SUE indicates that good earnings news decreases the negativity and pessimism of Q\&A discussions. These findings are all as expected, while the latter is reassuring regarding the construct validity of our linguistic variables. Also reassuring is the finding that higher market-to-book ratios (i.e., higher firm growth prospects) are associated with lower levels of tone negativity and pessimism, as the tone of discussion of investors' favorites - high M/B firms - is expected to be more positive. ${ }^{14}$ The

\footnotetext{
${ }^{12}$ Our results are similar, albeit somewhat statistically weaker, when we rerun the regression depicted by equation (1) on all conference call observations (i.e., without restricting the sample to EST + CST firms). This is as expected, since pooling the data in this way results in a less precise capture of the call participants' body clocks and states of fatigue (i.e., this results in pooling observations for East Coast participants' calls at 11 a.m., after several hours of work, with West Coast participants' calls at 8 a.m. local time, when they are fresh).

${ }^{13}$ Prior studies provide evidence of a "Friday effect" in firms' news disclosure strategies, with bad news being more likely to be released on Fridays (e.g., Damodaran (1989)). In untabulated analyses we rerun all of our linguistic variable and intraday market metric regressions with the inclusion of a Friday indicator variable. The variable is occasionally significant but never affects our economic inferences concerning the test variables of interest.

${ }^{14}$ The conservatism of GAAP, which prohibits the recognition of many economic gains (i.e., until they are crystallized via a third party transaction and thus verifiable), internally generated intangible assets, and the
} 
tone in the consumer and high tech sectors is relatively less negative than in other sectors, perhaps because conference calls in these widely watched sectors attract wider audiences, than in others, leading managers to "talk things up," or be more optimistic.

Similar to negativity, the L\&M textual TUncertainty measure (second column from right) is also increasing with the time of day, however Diction's measure of TCertainty (right column) is not significantly associated with EST_hour when other controls are included in the regression. The latter result is surprising since the univariate data in Table 4 suggest a strong trend of Diction TCertainty decreasing through the day. In untabulated sensitivity analyses, we find that EST_hour becomes significant when logAna is dropped from the regression, suggesting that the number of analysts is the dominant determinant of the textual TCertainty of the Q\&A, even more so than the time of day.

\subsection{Intraday Market Response to Conference Call Sentiment}

The findings reported in the previous section establish that the time at which a conference call is initiated influences the tone of the conversation between managers and analysts. In this section, we address Hypotheses 3 and 4 by investigating whether the changing tone of the Q\&A has economic implications in terms of the firm's stock returns and return volatilities. We use the following regressions to examine these hypotheses:

anticipated growth in future earnings derived from theseassets, suggests that GAAP earnings are a more limited information source regarding positive news for high $\mathrm{M} / \mathrm{B}$ firms than for other firms. Thus, it is not surprising that, in rich information environments such as the US publicly-traded markets, the "good news" that is prohibited from recognition in GAAP earnings gets conveyed by other means (i.e., via the tone of text) in the manner that our results would suggest. 
AbnRet $=\alpha+\beta_{1} S U E+\beta_{2} B A D+\beta_{3} S U E X B A D+\beta_{4}$ NetNegativity $+\beta_{5}$ TUncertainty + $\beta_{6}$ NetNegMgt $+\beta_{7}$ TUncMgt $+\beta_{8} \log T A+\beta_{9} \log M B+\beta_{10}$ EarnGrowth $1+$ $\beta_{11}$ EarnGrowth $2+\beta_{12}$ EarnGrowth $+\beta_{13}$ Industry $+\beta_{14}$ FiscalQtr $+\beta_{15}$ Year $+\varepsilon$

IntradayV $=\alpha+\beta_{1}$ absSUE $+\beta_{2}$ BAD $+\beta_{3}$ absSUEXBAD $+\beta_{4}$ NetNegativity $+\beta_{5}$ TUncertainty + $\beta_{6}$ NetNegMgt $+\beta_{7}$ TUncMgt $+\beta_{8} \log$ TA $+\beta_{9} \log \mathrm{BB}+\beta_{10}$ EarnGrowth1 $+\beta_{11}$ EarnGrowth2 + $\beta_{12}$ EarnGrowth3 $+\beta_{13}$ Industry $+\beta_{14}$ FiscalQtr $+\beta_{15}$ Year $+\varepsilon$

where the dependent variable AbnRet is the intraday 5-hour abnormal returns, and the dependent variable IntradayV is the intraday 5-hour abnormal volume or, alternatively, abnormal volatility. The earnings surprise (SUE) or its absolute value (absSUE) are, respectively, included to control for the signed and unsigned magnitude of the financial news that is being discussed in the call, $B A D$ is an indicator set to one when reported earnings miss analyst expectations, SUEXBAD and absSUEXBAD are alternatively included to allow the slope response to the earnings surprise to vary according to the sign of the news, $\log T A$ controls for firm size, EarnGrowth1 through EarnGrowth3 control for each of the next three quarter's realized earnings changes, while Industry, FiscalQtr, and Year are controls designed to capture any potential sector and year effects. ${ }^{15}$ We also control for both the negativity of the tone (NetNegMgt or NetPessMgt) and the textual uncertainty (TUncMgt or TCertMgt) of the preceding management presentation portion of the call, which provide good proxies for the respective tone measures of the associated

\footnotetext{
${ }^{15}$ In untabulated specification checks, we also include logMBXNetNegativity as an explanatory variable in order to allow the price impact of language to vary with the firm's growth prospects and unrecognized intangibles. For intangibles-intensive firms it is expected that tone may play a more important role, because current earnings do not adequately capture the firm's value-generating activities (Lev \& Zarowin (1999); Demers \& Vega (2012)). The variable is never significant, however, nor does it affect our inferences on the Negativity variable of interest in our primary test reported earlier.
} 
earnings announcement (Price et al. (2012)). For example, it may be that a particularly positive and sunny management presentation sets the tone of the subsequent Q\&A discussion. The test variables of interest in relation to our study's hypotheses are NetNegativity and NetPessimism in the intraday abnormal returns regression (2) and TUncertainty and TCertainty in the abnormal volume and volatility regressions (3).

In Table 6 we present the estimates from regressing 5-hour abnormal returns, volume, and return volatilities on our linguistic measures and controls. For this test, we include the EST + CST time zone calls beginning from $8: 00$ to $16: 59$, inclusive, and we begin the accumulation of returns (or the calculation of volume and volatility measures) at the start time of the call. For calls originating later in the day, the returns accumulation (or volume and volatility calculations) continues through to the first trading hours of the subsequent day. Certain prior studies examining the market response to conference call announcements have focused on more narrow time intervals, typically measuring the event window as 75-minutes, starting 15 minutes prior to the start of the call and ending 60 minutes after the start of the call (e.g., Bushee et al. (2003)). We prefer the 5-hour event window, given that prior studies find that linguistic tone gets incorporated into prices with a greater delay than earnings news (Engelberg (2008); Demers \& Vega (2012; Price et al. (2012)), so that a short, 75-minute window likely misses some of the tone's market impact. Furthermore, the 75-minute event window results in a considerable loss of observations for our sample because all calls that originate prior to 9:45 in the morning or after 15:00 in the afternoon must be discarded for lack of trading data. This significant loss of observations unduly reduces the power of our tests. Nevertheless, when we use a 75 -minute return window for our sample, we find qualitatively similar results to those reported below, although, as expected, at somewhat lower significance levels. 
The results from running equation (2) using 5-hour abnormal returns as the dependent variable are shown in the left two columns of Table 6. Consistent with Hypothesis 3, abnormal returns are negatively and significantly associated with the net negativity and net pessimism tone of conference calls, even after controlling for other expected determinants of the response of intraday returns to the information contained in the calls. ${ }^{16}$ The finding that abnormal returns are lower when the tone of the conference call conversation is more negative suggests that the market is responding to the tone of the Q\&A conversation over and above the impact of the control variables, particularly the earnings surprise and the tone of the management address that precedes the Q\&A session. In Section 4.5 we show that the negative market impact of the call tone is also economically meaningful.

The remaining regressions in Table 6 use alternative measures of shareholder disagreement as the dependent variables in equation (3). The third and fourth columns (from left) of Table 6 provide the results for the 5-hour abnormal volume. As shown, both the Diction-based measure, TCertainty, as well as the L\&M measure, TUncertainty, are significantly associated with abnormal volume. The sign of the coefficients suggest that, when the conversation between management and conference call participants is more resolute, direct and forthright, abnormal 5hour trading volume is higher: resoluteness enhances trading.

\footnotetext{
${ }^{16}$ Our results are robust to including positivity and negativity separately in the regression, rather than implicitly forcing the coefficient on these variables to be the same by using net negativity as our test variable. Our tests indicate that the coefficients on positivity and negativity are not significantly different, which enables us to collapse these two measures into a single variable, net negativity. We prefer to do this in order to be able to efficiently include language interaction terms in the extended regressions.
} 
The estimates in the right four columns of Table 6 use two alternative measures of intraday stock price volatility, the range of the stock's trading price and the standard deviation of the price during the 5-hour interval, as dependent variables. The results for both the Diction and L\&M certainty measures are similar across the alternative dependent variables, and also similar to the trade volume results reported above, indicating that higher textual certainty is associated with higher abnormal volatility. Assuming that textual certainty (textual uncertainty) captures the informedness, or precision (noisiness) of the Q\&A discussion about the value of the firm, then our volume and volatility findings are consistent with theoretical models suggesting that an increase in the informedness or precision of an information release will result in an increase in the volume and the variance of unexpected price changes (e.g., Holthausen and Verrecchia, 1990; Kim and Verrecchi, 1991 a and b). ${ }^{17}$ Overall, our market-based regression results indicate that the conference calls' time-of-day effect influences share price returns, volumes and volatilities via the systematically varying tone of the Q\&A discussion.

\subsection{What Determines the Time of Call?}

In the preceding sections we document that the time of day at which a conference call is initiated impacts the tone of the discussions between management and the firm's analysts, and that tone negativity is significantly associated with stock returns, volumes, and volatilities. Afternoon calls tend to be more negative in tone and thus adversely affect returns. Given that the time of the call's initiation has real consequences, and that managers are free to choose the time

\footnotetext{
${ }^{17}$ Our results are similar when we use a 3-day rather than 5-hour returns window.
} 
of their conference calls, we undertake some exploratory analyses in order to identify the factors that determine whether a call will be initiated in the morning or afternoon.

The results of logistic regressions with the dependent variable set to one for calls that are initiated during the afternoon trading hours, and zero otherwise, are presented in Table 7 . In the first, third, and fifth columns (from left) we exclude the indicator explanatory variable that is set equal to one if the firm's prior quarter call was held in the afternoon (lag_Afternoon). As shown, with this variable excluded from the regressions, reporting earnings that fall short of analyst expectations significantly increases the likelihood that the call will be held in the afternoon (i.e., the BAD news indicator variable has a significant and positive coefficient). In addition, firm size is inversely associated with the choice of an afternoon call (i.e., larger firms are less likely to hold calls in the afternoon), lending a certain credence to the morning "crowding out" conjecture mentioned earlier. High-tech firms are more likely to hold afternoon calls, probably due to the prevalence of Silicon Valley high-tech firms, which tend to initiate calls at times when West Coast participants are at their desks. Interestingly, the various alternative measures of equity dependence (EquiDepend1 and EquiDepend2) and investment intensity (InvestIntense), all as defined in the Appendix, are not significant determinants of call time. Given that afternoon calls generate more negative tone, leading to more negative abnormal returns (after controlling for the earnings news), it is surprising that firms that are most reliant on capital markets and thus most in need of investor approbation do not have greater propensities to hold their calls in the morning, during which time, as the evidence suggests, analysts are more receptive and congenial. One should, of course, entertain the possibility that some managers keep holding calls in the afternoon because they are simply unaware of our results. 
The second, fourth, and sixth columns of Table 7 report results for the same logistic regressions with the indicator variable for the prior quarter's choice of afternoon call included. As shown, having held the conference call in the afternoon for the previous quarter's earnings announcement is the most important determinant of whether the firm will initiate its call in the afternoon in the current quarter. This result is consistent with the descriptive evidence presented earlier that the time at which the call is initiated tends to be "sticky." Notably, once the prior quarter's call time is included in the regression, high-tech industry membership (HiTec) is no longer a significant determinant of the current quarter's call time, nor is falling short of analyst expectations $(B A D)$, and both equity dependence and investment intensity remain insignificant.

\subsection{Return Drifts and Reversions}

Our final set of analyses considers whether the 5-hour negative abnormal returns that are induced by the afternoon Q\&A discussions between managers and analysts tend to be permanent or transient in nature. We begin by examining graphically the returns patterns following morning- versus afternoon-initiated calls for each of the good and bad news earnings quarters, respectively. ${ }^{18}$ As shown in Figure 3, which depicts stock returns starting the day following the call, both morning and afternoon "good news" calls (top two curves in Figure 3) are associated with positive post-call abnormal returns, although the afternoon good news calls experience slightly lower positive drift over the 50-day post-call period. In contrast, both morning and afternoon calls related to "bad news" earnings (bottom two curves) result in initially negative

\footnotetext{
${ }^{18}$ We use our main sample of conference calls, those initiated by EST and CST firms between 8:00 and 16:59, for these analyses. Results are consistent when we use the unrestricted sample of all calls for EST and CST firms.
} 
post-call returns lasting, on average, for about seven days. After this initial decline, there is a notable returns reversal for both morning and afternoon "bad news" calls, with the reversal for afternoon calls being substantially stronger (i.e., abnormal returns are more positive). The graphical evidence is consistent with the market initially negatively over-reacting to bad news calls, followed by a subsequent correction.

The regression estimates presented in Table 8 examine the relation between the afternoon timing of the calls and returns patterns over various intervals, after controlling for other determinants of returns. For this multi-day returns analyses, we refer to day $\mathrm{t}=0$ as the trading day(s) during which 5-hour call period lasts and $\mathrm{t}=1$ as the first trading day after the day in which the 5-hour call period has ended. The dependent abnormal returns variables are size- and bookto-market-adjusted. For all windows we regress returns on an indicator variable (Afternoon) set to one for calls that are initiated during afternoon trading hours (and zero otherwise), as well as the earnings surprise (SUE), an indicator set to one if the firm's earnings fall below the analyst consensus estimate $(B A D)$, the interaction of the prior two variables (SUEXBAD), our alternative proxies for negative tone (NetNegativity and NetPessimism), and controls for size (logTA), unrecorded intangibles and growth expectations $(\log M B)$, the corresponding tone of the management address portion of the call (NetNegMgt and NetPessMg), and each of the next three quarter's realized earnings changes (EarnGrowth1, EarnGrowth2, and EarnGrowth3). Industry, fiscal quarter, and calendar year indicators are also included.

The 5-hour returns results in Table 8 (left columns) are similar to those reported earlier in Table 6, and are shown again here to provide a more complete perspective on the cross-temporal patterns of returns. As shown, the 5-hour call window abnormal returns are increasingly negative with the negative discussion tone. Importantly, controlling for the discussion tone, 
abnormal returns are not significantly different, on average, for morning versus afternoon calls (the Afternoon variable is insignificant), suggesting that other attributes of afternoon calls aren't significantly different than those of morning calls. ${ }^{19}$

Moving to the post-call period, the coefficients on $B A D$ in the third and fourth columns (from the left) in Table 8 show that there is a short-term drift of negative returns over the $[1,15]$ interval associated with both morning- and afternoon-initiated "bad earnings news" calls, even after controlling for the magnitude of the earnings news and tone. ${ }^{20}$ Furthermore, there are significant incremental negative returns drift in this early post-call period associated with the more financially robust L\&M measure of the negative tone of the Q\&A (NetNegativity), although the same effect is not evident using the cruder Diction measure (NetPessimism).

The estimates in the fourth and fifth columns (from left) of Table 8 examine the impact of the same variables on abnormal returns over the $[16,50]$ day period. ${ }^{21}$ As evidenced by the insignificant coefficients on the NetNegativity and NetPessimism variables, there is no further price drift associated with the tone of the Q\&A after the initial 15-day post-call period, nor, notably, is there a reversal of the previous drift. Our finding that the tone of the Q\&A only gets fully impounded into price with a delay (and that it does not reverse) is consistent with the results of prior financial linguistic studies (e.g., Engelberg (2008); Demers and Vega (2012)).

\footnotetext{
${ }^{19}$ In untabled results, we find that for large firms (defined as those in the $9^{\text {th }}$ and $10^{\text {th }}$ deciles of market capitalization), holding calls in the afternoon does have a significant direct negative impact upon abnormal returns beyond the discussion tone.

${ }^{20}$ Our results on the Afternoon indicator and tone variables of interest are consistent when we split the post-call period into $[1,8]$ and $[9,50]$ in order to capture the inflection points suggested by Figure 1 .

${ }^{21}$ Although we refer to this as the $[16,50]$ day period, we actually close the window on the earlier of the $50^{\text {th }}$ trading day or 2 days prior to the subsequent quarter's earnings announcement date in order to avoid having the subsequent quarter's earnings news confound our returns analyses related to the current quarter's call.
} 
This general finding in the literature is conjectured to be driven by the notion that language tone is relatively more difficult to process than the quantitative and well-understood earnings news.

Regarding an afternoon effect, distinct from call tone, for the $[16,50]$ period abnormal returns, there is a significant positive reversal of the negative drift due to afternoon calls (see the variable Afternoon) from the $[1,15]$ period. This is evidenced by the positive coefficients on the Afternoon indicator of 0.004 in the $[16,50]$ regressions which fully offset the coefficients of 0.003 from the earlier $[1,15]$ drift period. A similar reversal is noted for bad news calls, evidenced by the reversing coefficients on the $B A D$ indicator variable in the $[1,15]$ and $[16,50]$ regressions.

The regression results for the full $[0,50]$ period (right two columns) confirm the ephemeral nature of the direct negative impact of an afternoon call upon returns, distinct from the tone effect which doesn't reverse. As shown, there is no net negative (or positive) direct impact on abnormal returns over the $[0,50]$ period to holding an afternoon call. However, there is a lasting negative effect of the Q\&A tone upon returns, as evidenced by the significant coefficient on each of NetNegativity and NetPessimism, and this negative tone is in turn influenced by the time of day. Furthermore, this tone effect is economically significant. From Table 4 we see that moving the conference call time from 8:00 to 15:00, say, increases NetNegativity by $0.187(0.412-0.225)$. In Table 8 , the coefficient of NetNegativity for the $[0,50]$ period is -0.020 . Multiplying this 
coefficient by 0.187 yields -0.0037 for one quarter, and -0.015 or $-1.5 \%$ for four quarters. ${ }^{22}$ By comparison, the average annual returns to the S\&P 500 over the years of our sample was about $3 \%$.

\section{Summary and Conclusions}

Physical and mental fatigue, and the repetition of even simple mental tasks, tend to induce irritability, loss of self-control, and decline in executive function. We document, for the first time, the impact of these human physiological and mental factors - proxied by the time of dayon the tone of managerial communications with the firm's stakeholders in conference calls. Focusing on the Q\&A portion of earnings-related conference calls, a setting involving the natural and spontaneous use of language, we document that our empirical proxy for the mental and physiological state of call participants - the time of day — is a significant determinant of the tone of Q\&A discussions. Specifically, the tone of communications becomes more negative, less forthright, and less resolute as the morning progresses and fatigue sets in. The mood improves somewhat around the mid-day break, as call participants refresh, but then the discussion tone deteriorates again throughout the afternoon before improving after the market's close. On the whole, the linguistic tone of Q\&A discussions is significantly more negative and less resolute in the afternoon hours relative to the morning hours, even after controlling for other determinants of call tone, such as the sign and magnitude of the earnings surprise, whether the firm reported a loss for the quarter, firm size and growth, and the industry in which the firm operates.

\footnotetext{
${ }^{22}$ Notably, these findings are not being driven by small firms. In untabled results, we find that the coefficients of NetNegativity on large and small firms are not significantly different.
} 
The time of day and tone of communications between managers and analysts have real economic consequences: intraday stock returns, trading volume, and return volatilities are all responsive to linguistic tone. In particular, the tone negativity, which increases throughout the day, is associated with more negative abnormal stock returns. Notwithstanding all of these negative consequences to afternoon discussions, firms exhibit considerable "stickiness" when choosing the time at which to initiate calls; holding an afternoon call in the prior quarter is the single most important determinant of whether a firm will hold an afternoon call in the current quarter.

Our study should be of interest to academics and capital market participants, and particularly to firm managers. Executives have the option to choose the timing of their earnings-related conference call, thereby affecting the tone of conference call communications and its market consequences. We can only speculate at this stage on other adverse consequences of afternoon calls, such as fraying relations with analysts and investors. 


\section{References}

Baginski, Stephen, Demers, Elizabeth, Wang, Chong, \& Yu, Julia. (2012). The Pricing of Language in Management Forecast Press Releases. unpublished working paper.

Balakrishnan, Karthik, \& Bartov, Eli. (2011). Cognitive Bias, Conflicts of Interests, and Analysts' Use of Qualitative Earnings Information: Evidence from the IPO Prospectus's Risk Factors Section. unpublished working paper.

Baumeister, Roy. (2002). Ego Depletion and Self Control Failure: An Energy Model of the Self's Executive Function. Self and Identity, 1, 129-136.

Bushee, Brian J., Matsumoto, Dawn A., \& Miller, Gregory S. (2003). Open versus closed conference calls: the determinants and effects of broadening access to disclosure. Journal of Accounting \& Economics, 34(1-3), 149-180.

Bushee, Brian J., Matsumoto, Dawn A., \& Miller, Gregory S. (2004). Managerial and Investor Responses to Disclosure Regulation: The Case of Reg FD and Conference Calls. Accounting Review, 79(3), 617-643.

Chen, Carl R., \& Mohan, Nancy J. (1994). Timing the Disclosure of Information Management's View of Earnings Announcements. FM: The Journal of the Financial Management Association, 23(3), 63-69.

Coates, John. (2012). The Hour Between Dog and Wolf: Risk Taking, Gut Feelings and the Biology of Boom and Bust. London: Penguin Press.

Damodaran, A. (1989). The weekend effect in information releases: a study of earnings and dividend announcements. Review of Financial Studies, 2(4), 607-623.

Danziger, Shai, Levav, Jonathan, \& Avnaim-Pesso, Liora. (2011). Extraneous Factors in Judicial Decisions. Paper presented at the Proceedings of the National Academy of Sciences.

Davis, Angela, Piger, Jeremy, \& Sedor, Lisa. (2012). Beyond the Numbers: Measuring the Information Content of Earnings Press Release Language. Contemporary Accounting Research, forthcoming.

Demers, Elizabeth A., \& Vega, Clara. (2012). Textual Content in Earnings Press Releases: News or Noise? SSRN eLibrary.

Demers, Elizabeth, \& Yu, Julia. (2013). Linguistic Uncertainty in Managerial Announcements: A Review of the Literature and Preliminary Examination of Antecedents, Contemporaneous Disclosures and Consequences in the Context of Voluntarily Provided Earnings Forecasts. unpublished manuscript.

Engelberg, Joseph. (2008). Costly Information Processing: Evidence from Earnings Announcements. unpublished working paper, Northwestern University.

Francis, Jennifer, Pagach, Donald, \& Stephan, Jens. (1992). The Stock Market Response to Earnings Announcements Released during Trading versus Nontrading Periods. Journal of Accounting Research, 30(2), 165-184.

Frankel, Richard, Johnson, Marilyn, \& Skinner, Douglas. (1999). An Empirical Examination of Conference Calls as a Voluntary Disclosure Medium. Journal of Accounting Research, 37(1), 133-150.

Gailliot, M, \& Baumeister, Roy. (2007). The physiology of willpower: Linking blood glucose to self-control. Personality and Social Psychology Review, 11, 303-327.

Gailliot, Matthew T., \& Baumeister, Roy F. (2007). The Physiology of Willpower: Linking Blood Glucose to Self-Control. Personality and Social Psychology Review, 11(4), $303-$ 327. doi: $10.1177 / 1088868307303030$ 
Gennotte, G., \& Trueman, B. (1996). The strategic timing of corporate disclosures. Review of Financial Studies, 9(2), 665.

Hart, Roderick, \& Carroll, Craig. (2010). Diction 6.0: The Textual Analysis Program: Digitext, Inc.

Lev, Baruch, \& Zarowin. (1999). The Boundaries of Financial Reporting and How to Extend Them. Journal of Accounting Research, 37(2), 353-385.

Li, Feng. (2010). The Information Content of Forward-Looking Statements in Corporate FilingsA Naïve Bayesian Machine Learning Approach. Journal of Accounting Research, 48(5), 1049-1102. doi: 10.1111/j.1475-679X.2010.00382.x

Loughran, T., \& McDonald, B. (2011). When is a Liability Not a Liability? Journal of Finance, 66(February), 35-65.

Mangen, Claudine, \& Durnev, Artyom. (2010). The Real Effects of Disclosure Tone: Evidence from Restatements. SSRN eLibrary.

Matsumoto, Dawn, Pronk, Maarten, \& Roelofsen, Erik. (2011). What Makes Conference Calls Useful? The Information Content of Managers' Presentations and Analysts' Discussion Sessions. The Accounting Review, 86(4), 1383-1414.

Patell, James M., \& Wolfson, Mark A. (1982). Good News, Bad News, and the Intraday Timing of Corporate Disclosures. Accounting Review, 57(3), 509.

Price, S. McKay, Doran, James S., Peterson, David R., \& Bliss, Barbara A. (2012). Earnings conference calls and stock returns: The incremental informativeness of textual tone. Journal of Banking \& Finance, 36(4), 992-1011. doi: 10.1016/j.jbankfin.2011.10.013

Schoenfeld, Jordan. (2012). Immediate Belief Revisions of Analysts. unpublished working paper, University of Michigan.

Skinner, Douglas J. (2003). Should firms disclose everything to everybody? A discussion of "Open vs. closed conference calls: the determinants and effects of broadening access to disclosure", Editorial, Journal of Accounting \& Economics, pp. 181-187. Retrieved from http://ezproxy.insead.edu:80/login?url=http://search.ebscohost.com/login.aspx?direct=tru e\&db=bth\&AN=8762627\&site $=$ ehost-live

Tetlock, Paul C., Saar-Tsechansky, Maytal, \& Macskassy, Sofus. (2008). More Than Words: Quantifying Language to Measure Firms' Fundamentals. Journal of Finance, 63(3), 1437-1467. 


\section{Appendix}

\section{Summary of Variable Definitions}

\begin{tabular}{|c|c|}
\hline Variable & Definition \\
\hline Negativity & $\begin{array}{l}\text { Loughran and McDonald (2011) negativity score/WordCount in Q\&A*100. } \\
\text { We winsorize this variable by replacing values in the top } 99 \text { percentile with } \\
\text { the } 99 \text { percentile value and values in the bottom } 1 \text { percentile with the } 1 \\
\text { percentile value. }\end{array}$ \\
\hline NetNegativity & $\begin{array}{l}\text { Loughran and McDonald (2011) (negativity score - positivity } \\
\text { score)/WordCount in Q\&A*100. We winsorize this variable by replacing } \\
\text { values in the top } 99 \text { percentile with the } 99 \text { percentile value and values in the } \\
\text { bottom } 1 \text { percentile with the } 1 \text { percentile value. }\end{array}$ \\
\hline TUncertainty & $\begin{array}{l}\text { Loughran and McDonald (2011) uncertainty score/WordCount in Q\&A*100. } \\
\text { We winsorize this variable by replacing values in the top } 99 \text { percentile with } \\
\text { the } 99 \text { percentile value and values in the bottom } 1 \text { percentile with the } 1 \\
\text { percentile value. }\end{array}$ \\
\hline NegMgt & $\begin{array}{l}\text { Loughran and McDonald (2011) negativity/WordCount in conference call } \\
\text { manager presentation*100. We winsorize this variable by replacing values in } \\
\text { the top } 99 \text { percentile with the } 99 \text { percentile value and values in the bottom } 1 \\
\text { percentile with the } 1 \text { percentile value. }\end{array}$ \\
\hline NetNegMgt & $\begin{array}{l}\text { Loughran and McDonald (2011) net negativity/WordCount in conference call } \\
\text { manager presentation*100. We winsorize this variable by replacing values in } \\
\text { the top } 99 \text { percentile with the } 99 \text { percentile value and values in the bottom } 1 \\
\text { percentile with the } 1 \text { percentile value. }\end{array}$ \\
\hline TUncMgt & $\begin{array}{l}\text { Loughran and McDonald (2011) uncertainty/WordCount in conference call } \\
\text { manager presentation*100. We winsorize this variable by replacing values in } \\
\text { the top } 99 \text { percentile with the } 99 \text { percentile value and values in the bottom } 1 \\
\text { percentile with the } 1 \text { percentile value. }\end{array}$ \\
\hline Pessimism & $\begin{array}{l}\text { Diction } 6.0 \text { (blame+hardship }+ \text { denial } / \text { no. of words analysed in } Q \& A^{*} 100 \text {. } \\
\text { We winsorize this variable by replacing values in the top } 99 \text { percentile with } \\
\text { the } 99 \text { percentile value and values in the bottom } 1 \text { percentile with the } 1 \\
\text { percentile value. }\end{array}$ \\
\hline NetPessimism & $\begin{array}{l}\text { Diction 6.0 Pessimism - (praise+satisfaction+inspiration)/no. of words } \\
\text { analysed in Q\&A*100. We winsorize this variable by replacing values in the } \\
\text { top } 99 \text { percentile with the } 99 \text { percentile value and values in the bottom } 1 \\
\text { percentile with the } 1 \text { percentile value. }\end{array}$ \\
\hline
\end{tabular}




\begin{tabular}{|c|c|}
\hline TCertainty & $\begin{array}{l}\text { Redefined Diction } 6.0 \text { certainty/no. of words analyzed in Q\&A, and then } \\
\text { normalize this measure by adding the absolute value of the lowest (i.e., } \\
\text { negative) valued raw certainty score, dividing the sum through by the } \\
\text { maximum value, and then multiplying by } 100 \text {. Hence our Diction-based } \\
\text { certainty measure is also bounded by zero and } 100 \text {. We redefine the Diction } \\
6.0 \text { definition of certainty to be [Tenacity + Leveling + Collectives + } \\
\text { Insistence + Numerical Terms] - [Ambivalence + Self Reference + Variety]. } \\
\text { It is a textual variable that indicates the degree of "resoluteness," } \\
\text { "inflexibility," and "completeness" in the firm's conference call Q\&A } \\
\text { section. We winsorize this variable by replacing values in the top } 99 \\
\text { percentile with the } 99 \text { percentile value and values in the bottom } 1 \text { percentile } \\
\text { with the } 1 \text { percentile value. }\end{array}$ \\
\hline PessMgt & $\begin{array}{l}\text { Diction } 6.0 \text { pessimism/no. of words analyzed in conference call manager } \\
\text { presentation*100. We winsorize this variable by replacing values in the top } \\
99 \text { percentile with the } 99 \text { percentile value and values in the bottom } 1 \\
\text { percentile with the } 1 \text { percentile value. }\end{array}$ \\
\hline NetPessMgt & $\begin{array}{l}\text { Diction } 6.0 \text { net pessimism/no. of words analyzed in conference call manager } \\
\text { presentation*100. We winsorize this variable by replacing values in the top } \\
99 \text { percentile with the } 99 \text { percentile value and values in the bottom } 1 \\
\text { percentile with the } 1 \text { percentile value. }\end{array}$ \\
\hline TCerMgt & $\begin{array}{l}\text { Redefined Diction } 6.0 \text { certainty/no. of words analyzed in conference call } \\
\text { manager presentation, and then normalize this measure by adding the } \\
\text { absolute value of the lowest (i.e., negative) valued raw certainty score, } \\
\text { dividing the sum through by the maximum value, and then multiplying by } \\
100 \text {. We winsorize this variable by replacing values in the top } 99 \text { percentile } \\
\text { with the } 99 \text { percentile value and values in the bottom } 1 \text { percentile with the } 1 \\
\text { percentile value. }\end{array}$ \\
\hline AbnRet (5-hour) & $\begin{array}{l}\text { Trading price return in five trading hours after the start of conference calls } \\
\text { minus normal level of five hour trading price return calculated using return } \\
\text { for the same five hours in the same weekday during prior four weeks. } \\
\text { Trading price return=(last trading price-first trading price)/first trading price. } \\
\text { We winsorize this variable by replacing values in the top } 99 \text { percentile with } \\
\text { the } 99 \text { percentile value and values in the bottom } 1 \text { percentile with the } 1 \\
\text { percentile value. }\end{array}$ \\
\hline $\begin{array}{l}\text { AbnVolume } \\
\text { (5-hour) }\end{array}$ & $\begin{array}{l}\text { Trading volume in five trading hours after the start of conference calls } \\
\text { divided by normal level of five hour trading volume calculated using volume } \\
\text { for the same five hours in the same weekday during prior four weeks. We } \\
\text { winsorize this variable by replacing values in the top } 99 \text { percentile with the } \\
99 \text { percentile value and values in the bottom } 1 \text { percentile with the } 1 \text { percentile } \\
\text { value. }\end{array}$ \\
\hline $\begin{array}{l}\text { AbnPrange } \\
\text { (5-hour) }\end{array}$ & $\begin{array}{l}\text { Trading price range in five trading hours after the start of conference call } \\
\text { divided by normal level of five hour price range calculated using the same } \\
\text { five hours in the same weekday during prior four weeks. Price range= } \\
\text { (Highest trading price- lowest trading price)/lowest trading price. We } \\
\text { winsorize this variable by replacing values in the top } 99 \text { percentile with the } \\
99 \text { percentile value and values in the bottom } 1 \text { percentile with the } 1 \text { percentile } \\
\text { value. }\end{array}$ \\
\hline
\end{tabular}




\begin{tabular}{|c|c|}
\hline AbnPstd (5-hour) & $\begin{array}{l}\text { Trading price std in five trading hours after the start of conference call } \\
\text { divided by normal level of five hour price std calculated using the same five } \\
\text { hours in the same weekday during prior four weeks. Price std = Price } \\
\text { standard deviation/average trading price. We winsorize this variable by } \\
\text { replacing values in the top } 99 \text { percentile with the } 99 \text { percentile value and } \\
\text { values in the bottom } 1 \text { percentile with the } 1 \text { percentile value. }\end{array}$ \\
\hline EST_hour & The EST hour of day during which the call is initiated. \\
\hline SUE & $\begin{array}{l}\text { Earnings surprise }=\text { (actual - forecast)/std(actual-forecast). } \\
\text { We use IBES unadjusted mean estimate (MEANEST) as consensus forecast, } \\
\text { and unadjusted actuals (VALUE), which are then adjusted for stock splits. } \\
\text { We standardized the unexpected earnings by dividing the surprise over the } \\
\text { within-sample firm-specific standard deviation of the forecast error. For this } \\
\text { measure to be calculated, a firm should have at least } 3 \text { non-missing } \\
\text { unexpected earnings in the sample. We winsorize this variable by replacing } \\
\text { values in the top } 99 \text { percentile with the } 99 \text { percentile value and values in the } \\
\text { bottom } 1 \text { percentile with the } 1 \text { percentile value. }\end{array}$ \\
\hline absSUE & $\begin{array}{l}\text { Absolute value of SUE. We winsorize this variable by replacing values in } \\
\text { the top } 99 \text { percentile with the } 99 \text { percentile value and values in the bottom } 1 \\
\text { percentile with the } 1 \text { percentile value. }\end{array}$ \\
\hline$B A D$ & Dummy variable set to 1 if $\mathrm{SUE}<0$, and 0 otherwise. \\
\hline SUEXBAD & Crossing term of SUE and BAD \\
\hline absSUEXBAD & Crossing term of absSUE and BAD \\
\hline $\log T A$ & $\begin{array}{l}\text { The natural logarithm of total assets (ATQ in Compustat fundq database) at } \\
\text { the end of the current fiscal quarter. We winsorize this variable by replacing } \\
\text { values in the top } 99 \text { percentile with the } 99 \text { percentile value and values in the } \\
\text { bottom } 1 \text { percentile with the } 1 \text { percentile value. }\end{array}$ \\
\hline $\log A n a$ & $\begin{array}{l}\text { The natural logarithm of } 1 \text { plus the number of analysts following (NUMEST } \\
\text { in IBES summary history database) before the earnings conference call. We } \\
\text { winsorize this variable by replacing values in the top } 99 \text { percentile with the } \\
99 \text { percentile value and values in the bottom } 1 \text { percentile with the } 1 \text { percentile } \\
\text { value. }\end{array}$ \\
\hline $\log M B$ & $\begin{array}{l}\text { The natural logarithm of } 1 \text { plus market to book ratio (market capitalization } \\
\text { divided by book equity) of the firm at the end of the current fiscal quarter. } \\
\text { We winsorize this variable by replacing values in the top } 99 \text { percentile with } \\
\text { the } 99 \text { percentile value and values in the bottom } 1 \text { percentile with the } 1 \\
\text { percentile value. }\end{array}$ \\
\hline Loss & $\begin{array}{l}\text { Dummy variable set to } 1 \text { if net income for the current fiscal quarter is } \\
\text { negative, and } 0 \text { otherwise. }\end{array}$ \\
\hline EarnGrowth1 & $\begin{array}{l}\text { Net income in quarter } \mathrm{t}+1-\text { net income in quarter } \mathrm{t}-3) / \text { book value at the end } \\
\text { of quarter } \mathrm{t} \text {. We winsorize this variable by replacing values in the top } 99 \\
\text { percentile with the } 99 \text { percentile value and values in the bottom } 1 \text { percentile } \\
\text { with the } 1 \text { percentile value. }\end{array}$ \\
\hline EarnGrowth2 & $\begin{array}{l}\text { (Net income in quarter } \mathrm{t}+2 \text { - net income in quarter } \mathrm{t}-2 \text { )/book value at the end } \\
\text { of quarter } \mathrm{t} \text {. We winsorize this variable by replacing values in the top } 99 \\
\text { percentile with the } 99 \text { percentile value and values in the bottom } 1 \text { percentile } \\
\text { with the } 1 \text { percentile value. }\end{array}$ \\
\hline
\end{tabular}




\begin{tabular}{|c|c|}
\hline EarnGrowth3 & $\begin{array}{l}\text { Net income in quarter } t+3 \text { - net income in quarter } t-1) / \text { book value at the end } \\
\text { of quarter } t \text {. We winsorize this variable by replacing values in the top } 99 \\
\text { percentile with the } 99 \text { percentile value and values in the bottom } 1 \text { percentile } \\
\text { with the } 1 \text { percentile value. }\end{array}$ \\
\hline HighLev & $\begin{array}{l}\text { Dummy variable set to } 1 \text { if asset to equity ratio for the current fiscal quarter } \\
\text { is higher than } 2 \text {. }\end{array}$ \\
\hline LowLiquid & $\begin{array}{l}\text { Dummy variable set to } 1 \text { if current ratio (current asset divided by current } \\
\text { liability) for the current fiscal quarter is lower than } 1 \text {, and } 0 \text { otherwise. }\end{array}$ \\
\hline Cnsmr & $\begin{array}{l}\text { Fama French consumer industry indicator: Consumer Durables, } \\
\text { NonDurables, Wholesale, Retail, and Some Services (Laundries, Repair } \\
\text { Shops). }\end{array}$ \\
\hline$M f g$ & $\begin{array}{l}\text { Fama French manufacturer industry indicator: Manufacturing, Energy, and } \\
\text { Utilities. }\end{array}$ \\
\hline HiTec & $\begin{array}{l}\text { Fama French high-tech industry indicator: Business Equipment, Telephone } \\
\text { and Television Transmission. }\end{array}$ \\
\hline Hlth & $\begin{array}{l}\text { Fama French health industry indicator: Healthcare, Medical Equipment, and } \\
\text { Drugs. }\end{array}$ \\
\hline Finl & Financial industry with 4-digit SIC code between 6000 and 6999. \\
\hline CnsmrXEST_hour & Crossing term of Cnsmr and Est_hour \\
\hline MfgXEST_hour & Crossing term of Mfg and Est_hour \\
\hline HiTecXEST_hour & Crossing term of HiTec and Est_hour \\
\hline HIthXEST_hour & Crossing term of Hlth and Est_hour \\
\hline FinlXEST_hour & Crossing term of Finl and Est_hour \\
\hline FiscalQtr & Indicators of fiscal quarters. \\
\hline Afternoon & Indicator of the call initiated during 12:00-16:59 EST. \\
\hline EquiDepend1 & $\begin{array}{l}\text { Sum of net amount of equity issues in prior three fiscal years/sum of capital } \\
\text { expenditures in prior three fiscal years. Net amount of equity issues is } \\
\text { calculated as Compustat SSTK minus PRSTKC. We winsorize this variable } \\
\text { by replacing values in the top } 99 \text { percentile with the } 99 \text { percentile value and } \\
\text { values in the bottom } 1 \text { percentile with the } 1 \text { percentile value. }\end{array}$ \\
\hline EquiDepend2 & $\begin{array}{l}\text { (Sum of capital expenditures in prior three years-sum of cash flow from } \\
\text { operation in prior three years) /sum of capital expenditures in prior three } \\
\text { years. We winsorize this variable by replacing values in the top } 99 \text { percentile } \\
\text { with the } 99 \text { percentile value and values in the bottom } 1 \text { percentile with the } 1 \\
\text { percentile value. }\end{array}$ \\
\hline InvestIntense & $\begin{array}{l}\text { Sum of capital expenditures in prior three years/sum of property, plants and } \\
\text { equipments in prior three years. We winsorize this variable by replacing } \\
\text { values in the top } 99 \text { percentile with the } 99 \text { percentile value and values in the } \\
\text { bottom } 1 \text { percentile with the } 1 \text { percentile value. }\end{array}$ \\
\hline
\end{tabular}




\section{Figure 1 - Hourly “L\&M” Sentiment Levels (in EST time)}
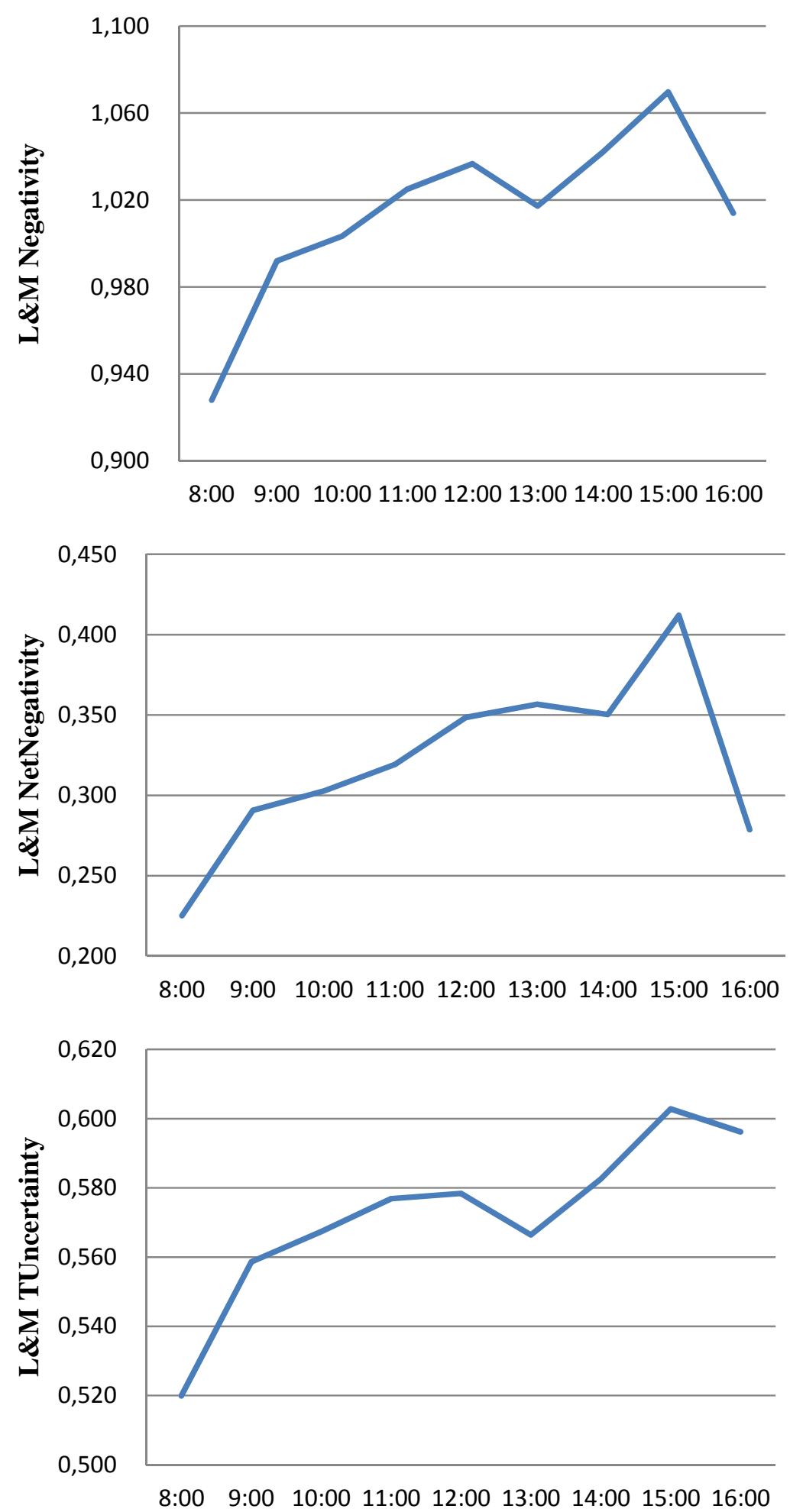
Figure 2 - Hourly “Diction” Sentiment Levels (in EST time)
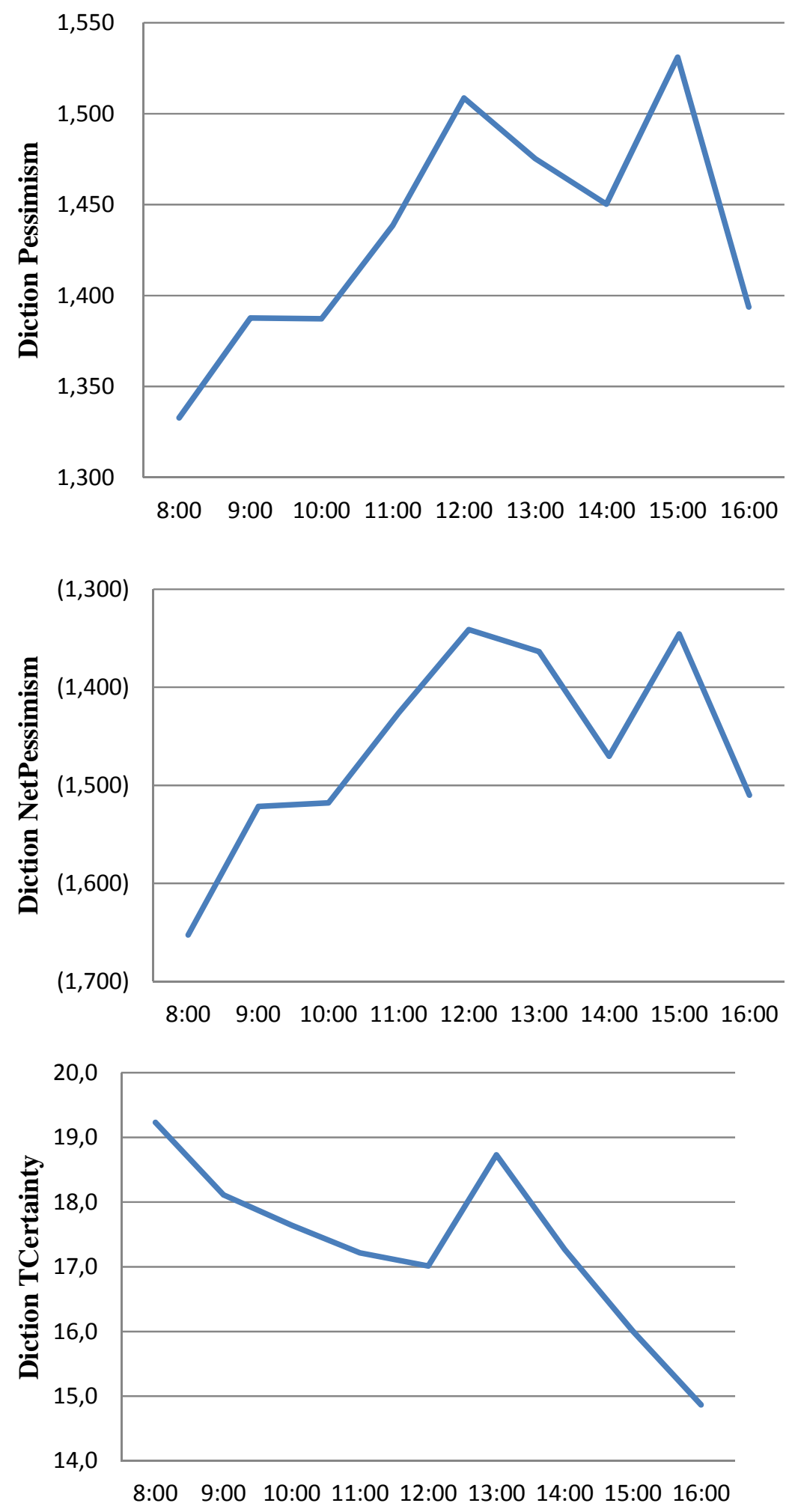


\section{Figure 3 - Abnormal Stock Performance Index for 50 post-call trading days}

This graph presents the 50-day post-call abnormal performance index for "bad news" and "good news" earnings quarters and for conference calls that are initiated in the morning and afternoon, respectively. "Bad news" quarters are defined as earnings that fall short of analyst consensus estimates, while "good news" quarters are those for which earnings meet or beat the analyst consensus. Returns accumulations begin on (i.e., day $\mathrm{t}=1$ is defined as) the first day after the day on which the 5-hour conference call returns interval ends.

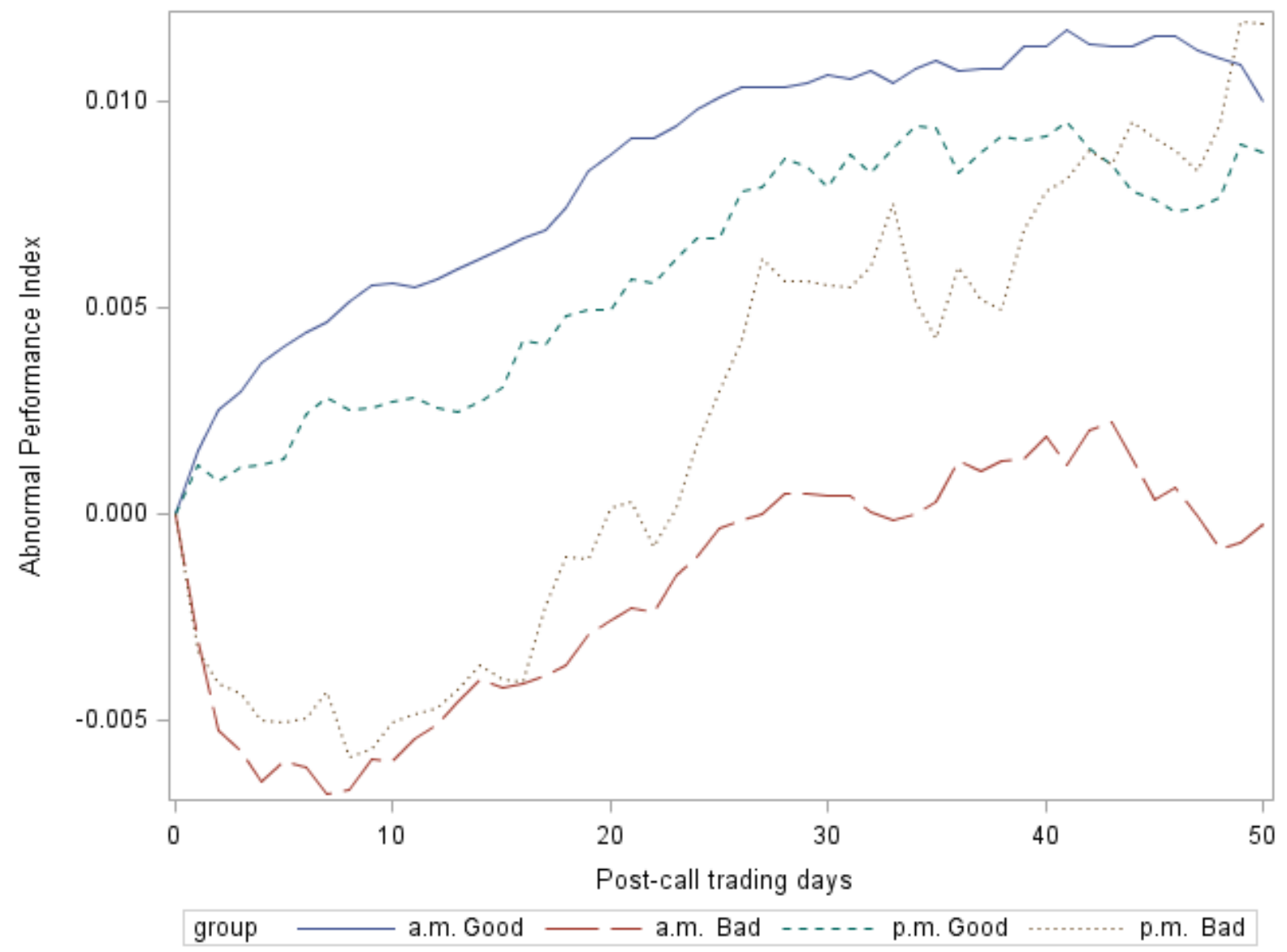

Note:

Abnormal Performance Index $=\frac{1}{\mathrm{~N}} \sum_{\mathrm{n}=1}^{\mathrm{N}}\left[\prod_{\mathrm{t}=1}^{\mathrm{T}}\left(1+\mathrm{r}_{\mathrm{t}}\right)-\prod_{\mathrm{t}=1}^{\mathrm{T}}\left(1+\mathrm{R}_{\text {size, }, \frac{\mathrm{B}}{\mathrm{M}} \mathrm{t}}\right)\right]$

Where,

$\mathrm{r}_{\mathrm{t}}=$ daily raw return of stock $n$ on date $t$

$\mathrm{R}_{\text {size }, \frac{\mathrm{B}}{\mathrm{M}}, \mathrm{t}}=$ daily avg. return of stocks in the same size \& $\frac{\mathrm{B}}{\mathrm{M}}$ group as stock $n$ on date $t$

$\mathrm{T}=1,2, \ldots, 50$

$\mathrm{N}=$ the number of stocks with $[1, \mathrm{~T}]$ cumulative abnormal return available on date $\mathrm{T}$ 
Table 1 - Sample Determination

\begin{tabular}{|c|c|c|}
\hline & No. Obs. & o. Firms \\
\hline Transcripts provided by Thomson StreetEvents from Jan2001 to Jun2007 & 96,839 & \\
\hline Word count from Q\&A section larger than 100 & 90,087 & \\
\hline Earnings release conference calls & 74,392 & \\
\hline Transcripts with city information available & 74,011 & \\
\hline Held by North American public companies ${ }^{1}$ & 64,593 & 5,850 \\
\hline Places of origination could be identified ${ }^{2}$ and are held in U.S cities & 48,524 & 3,542 \\
\hline Merge with CRSP database & 46,002 & 3,297 \\
\hline Merge with IBES database & 45,770 & 3,274 \\
\hline $\begin{array}{l}\text { Conference calls within the range of }[0,2] \text { days around earnings } \\
\text { announcement: }\end{array}$ & 43,218 & 3,215 \\
\hline After deleting remaining non-US (i.e., Canadian) firms & 43,073 & 3,201 \\
\hline Firms with non-negative book value of common equity & 41,852 & 3,147 \\
\hline Calls in Eastern and Central timezone & 29,533 & 2,213 \\
\hline Calls with start times between 8:00 to 16:59 Eastern Time ${ }^{4}$ & 26,585 & 2,113 \\
\hline
\end{tabular}

Notes:

1. Merged with Compustat NA database based on ticker and/or company name.

2. The transcripts provided by Thomson StreetEvents include the start time of the conference call stated in GMT format, which we extract together with the name of the city in which the call is initiated (the state and/or province and country of call origination are not provided). We then use the sashelp.zipcode file, which provides detailed location and time zone information for US cities, to translate the GMT start times into Eastern Time for consistency with the market hours being investigated in our study. For those cases where multiple cities of the same name confound the use of the SAS zip code function, we refer to the Compustat NA company file to identify the location of the firm's headquarter (CITY) and principal location (STATE). We use these Compustat variables together with the assumption that the call is originated in the firm's headquarter or principal location to infer the time zone in which the call was originated. We refer to official daylight savings start and end dates in each of GMT and Eastern Time zones in order to ensure that all GMT times extracted from the call transcripts have been correctly restated into Eastern Time.

3. Both the Compustat and IBES databases are used in identifying the earnings announcement date, and we retain the observation if the date of the call falls into the range of $[0,2]$ days of the earnings announcement date $(t=0)$ reported in either database. In cases where the observation falls into the $[0,2]$ day range in both databases but the earnings announcement dates reported in Compustat and IBES are not coincident, we rely upon rdq from the Compustat database to define the announcement date (i.e., for purposes of calculating other variables used in our tests).

4. In cases where all requisite financial data are not available to calculate regression the variables of interest, some of our analyses use less than the full sample of 26,585 observations. 
Table 2 - Descriptive Statistics

Panel A1: Sample firms and Compustat-IBES population

\begin{tabular}{lrrrrrr}
\hline Sample & $\mathbf{N}$ & Mean & Std Dev & 25th Pctl & Median & 75th Pctl \\
\hline Total Assets & 26,585 & $13,400.930$ & $79,496.580$ & 374.487 & $1,159.250$ & $4,087.970$ \\
Sales & 26,557 & $1,108.240$ & $3,576.450$ & 67.768 & 204.514 & 686.485 \\
Market Value & 26,489 & $5,934.650$ & $22,114.920$ & 376.576 & $1,045.370$ & $3,168.850$ \\
Market to Book & 26,489 & 5.860 & 240.014 & 1.528 & 2.191 & 3.398 \\
Analyst Following & 25,097 & 7.735 & 6.037 & 3.000 & 6.000 & 11.000 \\
\hline Compustat-IBES & $\mathbf{N}$ & Mean & Std Dev & 25th Pctl & Median & 75th Pctl \\
Population & & & & & & \\
\hline Total Assets & 93,683 & $7,033.250$ & $48,220.470$ & 178.099 & 669.399 & $2,394.960$ \\
Sales & 93,629 & 731.215 & $3,171.780$ & 23.806 & 92.784 & 352.213 \\
Market Value & 92,252 & $3,926.180$ & $16,714.770$ & 183.375 & 562.090 & $1,829.890$ \\
Market to Book & 92,051 & 9.744 & $1,731.660$ & 1.394 & 2.101 & 3.395 \\
Analyst Following & 93,829 & 6.147 & 5.877 & 2.000 & 4.000 & 8.000 \\
\hline
\end{tabular}

Panel A2: Sample firms and Compustat-IBES population: incidence of Loss and Meet-orbeat

\begin{tabular}{|c|c|c|c|c|}
\hline & \multicolumn{2}{|c|}{ Sample } & \multicolumn{2}{|c|}{ Compustat (IBES) Population } \\
\hline & $\mathbf{N}$ & Percentage & $\mathbf{N}$ & Percentage \\
\hline Incidence of Loss & 5,000 & $19 \%$ & 26,353 & $28 \%$ \\
\hline $\begin{array}{l}\text { Incidence of Meet- } \\
\text { or-beat }\end{array}$ & 17,630 & $71 \%$ & 62,385 & $67 \%$ \\
\hline
\end{tabular}

Panel A3: Sample firms and Compustat-IBES population: industry compostion

\begin{tabular}{lrr|rr}
\hline \multirow{2}{*}{ Industry Section } & \multicolumn{2}{c|}{ Sample } & Compustat (IBES) Population \\
\cline { 2 - 5 } & $\mathbf{N}$ & Percentage & $\mathbf{N}$ & Percentage \\
\hline Cnsmr & 5,007 & $19 \%$ & 14,246 & $15 \%$ \\
Mfg & 6,448 & $24 \%$ & 16,083 & $17 \%$ \\
HiTec & 4,210 & $16 \%$ & 23,907 & $25 \%$ \\
Hlth & 2,667 & $10 \%$ & 10,870 & $12 \%$ \\
Finl & 4,902 & $18 \%$ & 18,140 & $19 \%$ \\
Other & 3,351 & $13 \%$ & 10,583 & $11 \%$ \\
\hline Total & 26,585 & \multicolumn{3}{c}{93,829} \\
\end{tabular}


Table 2 - Descriptive Statistics (continued)

Panel B: Other firms charate ris tics

\begin{tabular}{lrrrrrr}
\hline & N & Mean & Std Dev & 25th Pctl & Median & 75th Pctl \\
\hline Negativity & 26,585 & 1.004 & 0.335 & 0.781 & 0.936 & 1.139 \\
NetNegativity & 26,585 & 0.301 & 0.304 & 0.113 & 0.277 & 0.459 \\
TUncertainty & 26,585 & 0.567 & 0.198 & 0.433 & 0.525 & 0.653 \\
NegMgt & 26,542 & 1.287 & 0.402 & 0.998 & 1.226 & 1.503 \\
NetNegMgt & 26,542 & 0.115 & 0.455 & $(0.185)$ & 0.093 & 0.390 \\
TUncMgt & 26,542 & 0.633 & 0.233 & 0.471 & 0.599 & 0.754 \\
Pessimism & 26,585 & 1.405 & 0.399 & 1.127 & 1.380 & 1.656 \\
NetPessimism & 26,585 & $(1.497)$ & 0.744 & $(1.966)$ & $(1.461)$ & $(0.993)$ \\
TCertainty & 26,585 & 17.499 & 9.453 & 10.247 & 16.863 & 23.859 \\
PessMgt & 26,542 & 0.748 & 0.330 & 0.509 & 0.698 & 0.930 \\
NetPessMgt & 26,542 & $(1.654)$ & 0.775 & $(2.138)$ & $(1.602)$ & $(1.110)$ \\
TCerMgt & 26,542 & 22.849 & 7.508 & 17.373 & 21.861 & 27.282 \\
AbnRet (5-hour) & 23,455 & $(0.000)$ & 0.036 & $(0.017)$ & $(0.000)$ & 0.017 \\
AbnVolume (5-hour) & 23,455 & 3.202 & 3.498 & 1.248 & 2.076 & 3.702 \\
AbnPrange (5-hour) & 23,448 & 2.126 & 1.561 & 1.104 & 1.692 & 2.625 \\
AbnPstd (5-hour) & 23,434 & 1.997 & 1.444 & 1.007 & 1.591 & 2.535 \\
Net Income & 26,558 & 82.625 & 605.085 & 1.563 & 11.197 & 44.160 \\
SUE & 24,832 & 0.297 & 1.067 & $(0.183)$ & 0.217 & 0.857 \\
EarnGrowth1 & 26,484 & 0.011 & 0.092 & $(0.007)$ & 0.005 & 0.018 \\
EarnGrowth2 & 26,455 & 0.011 & 0.091 & $(0.007)$ & 0.005 & 0.019 \\
EarnGrowth3 & 26,356 & 0.011 & 0.095 & $(0.008)$ & 0.005 & 0.019 \\
Leverage & 26,585 & 5.327 & 112.984 & 1.618 & 2.276 & 3.581 \\
Current Ratio & 21,780 & 2.544 & 2.598 & 1.272 & 1.847 & 2.851 \\
\hline & & & & & &
\end{tabular}


Table 3 - Conference calls initiated in Eastern and Central time zones

Panel A: Number of calls a firm held during the sample period (Jan 2001 to Jun 2007)

\begin{tabular}{rrrrrr} 
no. of firms & no. of calls & Mean & Std Dev & Min & Max \\
2,213 & 29,533 & 13.345 & 7.047 & 1.000 & 41.000 \\
\hline
\end{tabular}

Panel B1: Stickiness of conference call start time

\begin{tabular}{rrr}
\hline & no. of firms & percentage \\
stickiness & 688 & $33 \%$ \\
no stickiness & 1,388 & $67 \%$ \\
\hline Total & 2,076 & \\
\cline { 1 - 3 } Stickiness defined as $\mathbf{7 5 \%}$ of time & no. of firms & percentage \\
stickiness & 1,361 & $66 \%$ \\
no stickiness & 715 & $34 \%$ \\
\hline Total & 2,076 &
\end{tabular}

Panel B2: Change call start time due to loss or miss

\begin{tabular}{crc}
\hline & Change time & No change \\
Loss or miss & 551 & 6,735 \\
& $7.56 \%$ & $92.44 \%$ \\
Good news & 832 & 11,173 \\
& $6.93 \%$ & $93.07 \%$ \\
\hline \multicolumn{4}{c}{ Chi-square $=2.72, \mathrm{p}=0.0990$}
\end{tabular}

Panel C: Stickiness on holding conference call within (outside of) mkt hours

\begin{tabular}{rrr}
\hline & no. of firms & percentage \\
Only within mkt hour & 859 & $41 \%$ \\
Only outside of mkt hour & 507 & $24 \%$ \\
no stickiness & 710 & $35 \%$ \\
\hline Total & 2,076 \\
\cline { 3 - 3 }
\end{tabular}

Panel D1: Stickness for sticky calls within mkt hours

\begin{tabular}{rrr} 
& no. of firms & percentage \\
Only in morning (before 12:00) & 561 & $65 \%$ \\
Only in afternoon & 54 & $6 \%$ \\
no stickiness & 244 & $29 \%$ \\
\hline Total & 859 & \\
\hline Panel D2: Stickness for sticky calls outside mkt hours \\
\hline no. of firms & percentage \\
Only in morning (before 9:30) & 189 & $37 \%$ \\
Only in afternoon(after 16:00) & 191 & $38 \%$ \\
no stickiness & 127 & $25 \%$ \\
\hline Total & 507 \\
\cline { 2 - 3 }
\end{tabular}


Table 3 - Conference calls initiated in Eastern and Central time zones (continued)

Panel E: Stickness for calls only in morning or only in afternoon

\begin{tabular}{rrr}
\hline & no. of firms & percentage \\
Only before 8:00 & 1 & $0 \%$ \\
Only 8:00-8:59 & 71 & $7 \%$ \\
Only 9:00-9:59 & 83 & $8 \%$ \\
Only 10:00-10:59 & 189 & $19 \%$ \\
Only 11:00-11:59 & 191 & $19 \%$ \\
Only 12:00-12:59 & 7 & $1 \%$ \\
Only 13:00-13:59 & 6 & $1 \%$ \\
Only 14:00-14:59 & 22 & $2 \%$ \\
Only 15:00-15:59 & 7 & $1 \%$ \\
Only 16:00-16:59 & 64 & $6 \%$ \\
Only after 17:00 & 84 & $8 \%$ \\
no stickiness & 270 & $27 \%$ \\
\hline Total & 995 &
\end{tabular}

\section{Panel F1: Meet or Beat (SUE $>=0$ )}

\begin{tabular}{rrr}
\hline & no. of calls & percentage \\
before mkt hour & 4,440 & $23 \%$ \\
Within mkt hour(a.m.) & 9,804 & $51 \%$ \\
Within mkt hour(p.m.) & 1,550 & $8 \%$ \\
after mkt hour & 3,371 & $18 \%$ \\
\hline Subtotal & 19,165 & \\
\cline { 2 - 3 } Panel F2: Bad newsSUE & & \\
\hline & no. of calls & percentage \\
before mkt hour & 1,606 & $19 \%$ \\
Within mkt hour(a.m.) & 4,477 & $53 \%$ \\
Within mkt hour(p.m.) & 847 & $10 \%$ \\
after mkt hour & 1,477 & $18 \%$ \\
\hline Subtotal & 8,407 & \\
\cline { 2 - 3 } Total & 27,572 & \\
\cline { 2 - 3 } &
\end{tabular}

Note:

Panel A starts with 29,533 calls for 2,213 firms. For the analyses in Panels A through E, firms with only one call in the sample period are deleted, leaving 29,396 calls for 2,076 firms. Panel F requires call observations to have SUE available, resulting in a reduced sample of 27,572 calls. Panel F1 includes conference calls with announced earnings that meet or beat the analysis consensus estimate, while Panel F2 includes conference calls with announced earnings that are below the analyst consensus estimate. 
Table 4 - Hourly Sentiment Levels (in Eastern Time)

Panel A:For Eastern \& Central sample only

\begin{tabular}{|c|c|c|c|c|c|c|c|}
\hline \multirow{2}{*}{ Est_Hour } & \multirow{2}{*}{ No. of Obs } & \multicolumn{3}{|c|}{ LM Measures } & \multicolumn{3}{|c|}{ Diction Measures } \\
\hline & & Negativity & NetNegativity & TUnce rtainty & Pessimism & NetPessimism & TCertainty \\
\hline $8: 00-8: 59$ & 2,955 & 0.928 & 0.225 & 0.520 & 1.333 & (1.653) & 19.232 \\
\hline 10:00-10:59 & 7,449 & 1.003 & 0.303 & 0.567 & 1.387 & (1.518) & 17.641 \\
\hline 11:00-11:59 & 7,208 & 1.025 & 0.319 & 0.577 & 1.439 & $(1.426)$ & 17.217 \\
\hline $12: 00-12: 59$ & 333 & 1.037 & 0.348 & 0.578 & 1.509 & $(1.341)$ & 17.012 \\
\hline $14: 00-14: 59$ & 1,150 & 1.042 & 0.350 & 0.583 & 1.450 & $(1.470)$ & 17.268 \\
\hline $15: 00-15: 59$ & 540 & 1.070 & 0.412 & 0.603 & 1.531 & (1.346) & 16.003 \\
\hline $16: 00-16: 59$ & 2,324 & 1.014 & 0.279 & 0.596 & 1.394 & (1.510) & 14.868 \\
\hline
\end{tabular}

Total No. of Obs

26,585

Panel B :For all calls

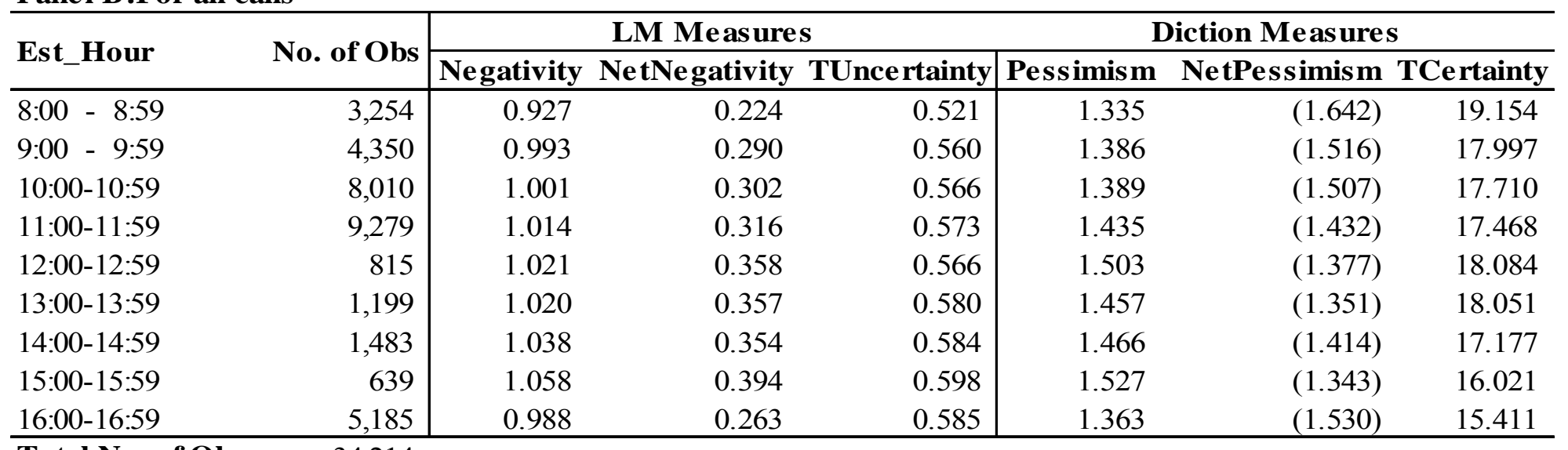

Total No. of Obs

34,214 
Table 5 - Regression of Call Sentiment on Time of Day and Control Variables

\begin{tabular}{|c|c|c|c|c|c|c|}
\hline \multirow{2}{*}{ Intercept } & \multicolumn{6}{|c|}{ Negativity NetNegativity Pessimism NetPessimism TUnce rtainty TCertainty } \\
\hline & $\begin{array}{c}1.049^{* * *} \\
(30.85)\end{array}$ & $\begin{array}{c}0.231 * * * \\
(9.20)\end{array}$ & $\begin{array}{c}0.930^{* * * *} \\
(19.20)\end{array}$ & $\begin{array}{c}-1.288^{* * *} \\
(15.49)\end{array}$ & $\begin{array}{c}0.671^{* * *} \\
(30.18)\end{array}$ & $\begin{array}{c}4.139 * * * \\
(3.22)\end{array}$ \\
\hline EST_hour & $\begin{array}{c}0.005^{* *} \\
(2.34)\end{array}$ & $\begin{array}{c}0.008^{* * *} \\
(5.09)\end{array}$ & $\begin{array}{c}0.014 * * * \\
(4.82)\end{array}$ & $\begin{array}{c}0.014 * * * \\
(2.82)\end{array}$ & $\begin{array}{c}0.003^{* *} \\
(2.36)\end{array}$ & $\begin{array}{l}-0.090 \\
(1.24)\end{array}$ \\
\hline SUE & $\begin{array}{c}-0.006^{* * *} \\
(2.82)\end{array}$ & $\begin{array}{c}-0.020 * * * \\
(9.49)\end{array}$ & $\begin{array}{c}-0.021 * * * \\
(6.37)\end{array}$ & $\begin{array}{c}-0.064 * * * \\
(11.37)\end{array}$ & $\begin{array}{c}0.003 * * \\
(2.30)\end{array}$ & $\begin{array}{c}-0.297 * * * \\
(4.00)\end{array}$ \\
\hline NegMgt & $\begin{array}{c}0.107^{* * *} \\
(11.32)\end{array}$ & & & & & \\
\hline NetNegMgt & & $\begin{array}{c}0.175^{* * * *} \\
(26.22)\end{array}$ & & & & \\
\hline PessMgt & & & $\begin{array}{c}0.366^{* * *} \\
(23.81)\end{array}$ & & & \\
\hline NetPessMgt & & & & $\begin{array}{c}0.288 * * * \\
(25.01)\end{array}$ & & \\
\hline TUncMgt & & & & & $\begin{array}{c}0.062^{* * * *} \\
(6.10)\end{array}$ & \\
\hline TCerMgt & & & & & & $\begin{array}{l}-0.031 \\
(1.57)\end{array}$ \\
\hline $\log T A$ & $\begin{array}{c}0.011^{* * *} \\
(3.45)\end{array}$ & $\begin{array}{c}0.011^{* * *} \\
(4.25)\end{array}$ & $\begin{array}{c}0.015^{* * *} \\
(2.93)\end{array}$ & $\begin{array}{c}0.018^{* *} \\
(2.00)\end{array}$ & $\begin{array}{l}-0.003 \\
(1.37)\end{array}$ & $\begin{array}{c}0.635 * * * \\
(4.35)\end{array}$ \\
\hline $\log A n a$ & $\begin{array}{c}-0.146 * * * \\
(20.59)\end{array}$ & $\begin{array}{c}-0.044 * * * \\
(7.37)\end{array}$ & $\begin{array}{l}0.003 \\
(0.25)\end{array}$ & $\begin{array}{l}-0.007 \\
(0.37)\end{array}$ & $\begin{array}{c}-0.076^{* * * *} \\
(16.42)\end{array}$ & $\begin{array}{c}4.858^{* * * *} \\
(17.91)\end{array}$ \\
\hline $\log M B$ & $\begin{array}{c}-0.045^{* * *} \\
(5.75)\end{array}$ & $\begin{array}{c}-0.033^{* * *} \\
(5.20)\end{array}$ & $\begin{array}{l}-0.017 \\
(1.40)\end{array}$ & $\begin{array}{l}-0.030 \\
(1.42)\end{array}$ & $\begin{array}{c}-0.016^{* * *} \\
(3.15)\end{array}$ & $\begin{array}{c}1.200^{* * *} \\
(3.70)\end{array}$ \\
\hline Loss & $\begin{array}{l}0.011 \\
(1.20)\end{array}$ & $\begin{array}{l}0.014^{*} \\
(1.93)\end{array}$ & $\begin{array}{c}-0.079 * * * \\
(6.73)\end{array}$ & $\begin{array}{l}-0.009 \\
(0.46)\end{array}$ & $\begin{array}{l}0.003 \\
(0.54)\end{array}$ & $\begin{array}{c}-0.501^{*} \\
(1.76)\end{array}$ \\
\hline EarnGrowth1 & $\begin{array}{l}0.005 \\
(0.21)\end{array}$ & $\begin{array}{l}-0.023 \\
(1.07)\end{array}$ & $\begin{array}{c}-0.046^{*} \\
(1.66)\end{array}$ & $\begin{array}{l}-0.056 \\
(1.15)\end{array}$ & $\begin{array}{c}0.033^{* *} \\
(2.35)\end{array}$ & $\begin{array}{l}-0.797 \\
(1.28)\end{array}$ \\
\hline EarnGrowth2 & $\begin{array}{l}-0.001 \\
(0.03)\end{array}$ & $\begin{array}{l}0.002 \\
(0.08)\end{array}$ & $\begin{array}{l}-0.056^{*} \\
(1.91)\end{array}$ & $\begin{array}{c}-0.117^{* *} \\
(2.31)\end{array}$ & $\begin{array}{l}0.004 \\
(0.34)\end{array}$ & $\begin{array}{l}-0.437 \\
(0.72)\end{array}$ \\
\hline EarnGrowth3 & $\begin{array}{l}-0.008 \\
(0.39)\end{array}$ & $\begin{array}{l}-0.020 \\
(1.02)\end{array}$ & $\begin{array}{l}-0.052^{*} \\
(1.86)\end{array}$ & $\begin{array}{l}-0.045 \\
(0.92)\end{array}$ & $\begin{array}{l}-0.014 \\
(0.94)\end{array}$ & $\begin{array}{l}-0.716 \\
(1.19)\end{array}$ \\
\hline HighLev & $\begin{array}{c}0.019^{* *} \\
(2.45)\end{array}$ & $\begin{array}{l}0.012 * \\
(1.72)\end{array}$ & $\begin{array}{l}-0.004 \\
(0.36)\end{array}$ & $\begin{array}{l}-0.000 \\
(0.02)\end{array}$ & $\begin{array}{l}0.002 \\
(0.37)\end{array}$ & $\begin{array}{l}0.107 \\
(0.34)\end{array}$ \\
\hline LowLiquid & $\begin{array}{c}0.029^{* * *} \\
(2.65)\end{array}$ & $\begin{array}{c}0.032 * * * \\
(3.77)\end{array}$ & $\begin{array}{l}-0.028^{*} \\
(1.92)\end{array}$ & $\begin{array}{c}-0.073 * * * \\
(2.88)\end{array}$ & $\begin{array}{c}0.033^{* * *} \\
(5.18)\end{array}$ & $\begin{array}{c}-2.391 * * * \\
(5.94)\end{array}$ \\
\hline CnsmrXEST_Hour & $\begin{array}{c}-0.004^{* * * *} \\
(3.20)\end{array}$ & $\begin{array}{c}-0.008^{* * *} \\
(7.44)\end{array}$ & $\begin{array}{c}-0.003 * \\
(1.81)\end{array}$ & $\begin{array}{c}-0.006^{*} \\
(1.90)\end{array}$ & $\begin{array}{c}-0.003 * * * \\
(3.08)\end{array}$ & $\begin{array}{l}0.027 \\
(0.58)\end{array}$ \\
\hline MfgXEST_hour & $\begin{array}{c}-0.003 * * \\
(2.17)\end{array}$ & $\begin{array}{c}-0.002^{*} \\
(1.70)\end{array}$ & $\begin{array}{l}-0.002 \\
(1.31)\end{array}$ & $\begin{array}{c}0.006^{* *} \\
(2.01)\end{array}$ & $\begin{array}{l}0.001 \\
(0.85)\end{array}$ & $\begin{array}{l}-0.005 \\
(0.11)\end{array}$ \\
\hline HiTecXEST_hour & $\begin{array}{c}-0.004^{* * *} \\
(3.07) \\
\end{array}$ & $\begin{array}{c}-0.005^{* * *} \\
(4.70)\end{array}$ & $\begin{array}{c}-0.007 * * * \\
(3.71) \\
\end{array}$ & $\begin{array}{l}-0.005 \\
(1.63) \\
\end{array}$ & $\begin{array}{l}-0.001 \\
(1.24) \\
\end{array}$ & $\begin{array}{l}-0.027 \\
(0.54) \\
\end{array}$ \\
\hline
\end{tabular}


Table 5 - Regression of Call Sentiment on Time of Day and Control Variables (continued)

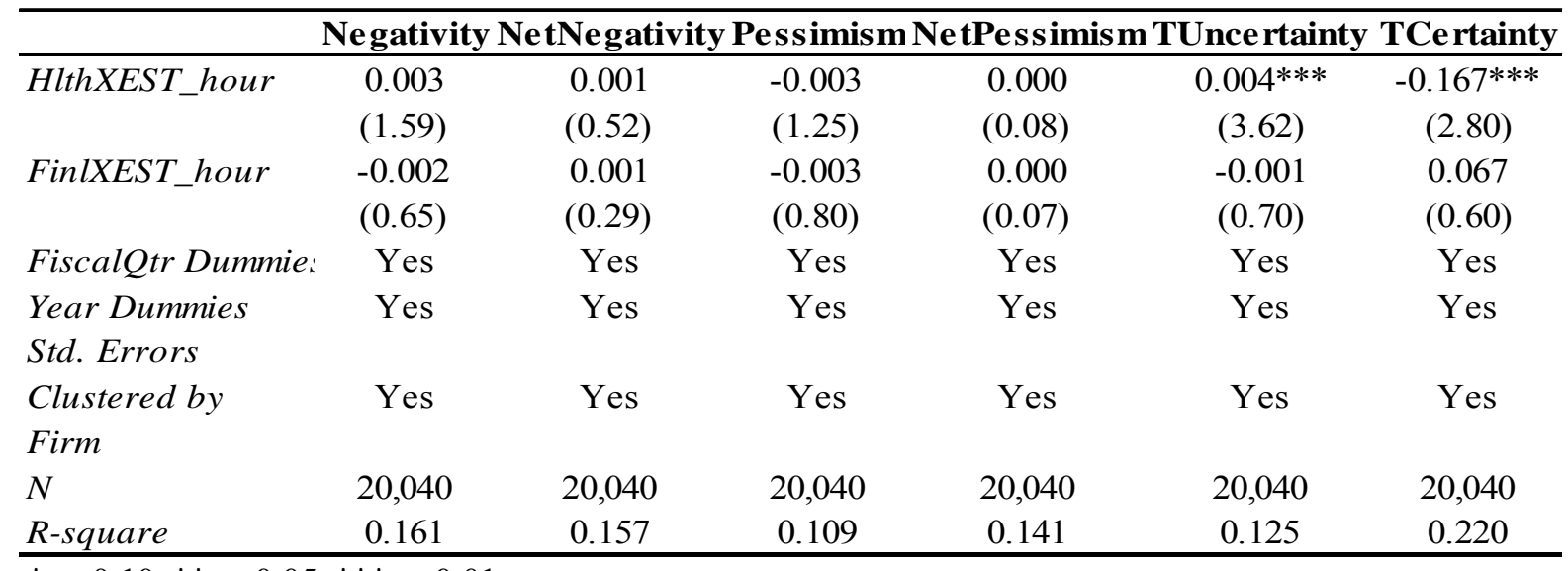

$* \mathrm{p}<0.10, * * \mathrm{p}<0.05, * * * \mathrm{p}<0.01$ 
Table 6 - Regression of 5-hour Intraday Market Response on Call Sentiment

\begin{tabular}{|c|c|c|c|c|c|c|c|c|}
\hline & AbnRet & AbnRet & Intraday V & IntradayV & AbnPrange & AbnPrange & AbnPstd & AbnPstd \\
\hline Intercept & $\begin{array}{l}-0.001 \\
(0.32)\end{array}$ & $\begin{array}{l}-0.003^{*} \\
(1.71)\end{array}$ & $\begin{array}{l}5.658^{* * * *} \\
(20.18)\end{array}$ & $\begin{array}{l}4.441^{* * * *} \\
(16.89)\end{array}$ & $\begin{array}{l}2.699 \text { *** } \\
(22.92)\end{array}$ & $\begin{array}{l}2.215^{* * *} \\
(21.63)\end{array}$ & $\begin{array}{l}2.559^{* * * *} \\
(23.87)\end{array}$ & $\begin{array}{l}2.144^{* * * *} \\
(24.00)\end{array}$ \\
\hline SUE & $\begin{array}{l}0.003^{* * *} \\
(6.83)\end{array}$ & $\begin{array}{l}0.003^{* * *} \\
(6.90)\end{array}$ & & & & & & \\
\hline absSUE & & & $\begin{array}{l}0.421^{* * *} \\
(11.33)\end{array}$ & $\begin{array}{l}0.418^{* * * *} \\
(11.26)\end{array}$ & $\begin{array}{l}0.078^{* * * *} \\
(4.79)\end{array}$ & $\begin{array}{l}0.077^{* * *} \\
(4.70)\end{array}$ & $\begin{array}{l}0.055^{* * *} \\
(3.70)\end{array}$ & $\begin{array}{l}0.054^{* * *} \\
(3.63)\end{array}$ \\
\hline$B A D$ & $\begin{array}{l}-0.002 * * * \\
(2.91)\end{array}$ & $\begin{array}{l}-0.002 * * * \\
(2.78)\end{array}$ & $\begin{array}{l}0.265^{* * * *} \\
(3.27)\end{array}$ & $\begin{array}{l}0.246^{* * * *} \\
(3.07)\end{array}$ & $\begin{array}{l}0.047 \\
(1.23)\end{array}$ & $\begin{array}{l}0.044 \\
(1.15)\end{array}$ & $\begin{array}{l}0.024 \\
(0.68)\end{array}$ & $\begin{array}{l}0.018 \\
(0.52)\end{array}$ \\
\hline SUEXBAD & $\begin{array}{l}-0.003^{* * * *} \\
(3.91)\end{array}$ & $\begin{array}{l}-0.003 * * * \\
(3.94)\end{array}$ & & & & & & \\
\hline absSUEXBAD & & & $\begin{array}{l}0.061 \\
(0.71)\end{array}$ & $\begin{array}{l}0.058 \\
(0.68)\end{array}$ & $\begin{array}{l}0.079^{* *} \\
(2.22)\end{array}$ & $\begin{array}{l}0.080^{* *} \\
(2.24)\end{array}$ & $\begin{array}{l}0.082 * * \\
(2.50)\end{array}$ & $\begin{array}{l}0.081^{* *} \\
(2.50)\end{array}$ \\
\hline NetNegativity & $\begin{array}{l}-0.003 * * * \\
(3.46)\end{array}$ & & $\begin{array}{l}0.069 \\
(0.70)\end{array}$ & & $\begin{array}{l}0.050 \\
(1.17)\end{array}$ & & $\begin{array}{l}0.056 \\
(1.43)\end{array}$ & \\
\hline NetPessimism & & $\begin{array}{l}-0.001 * * * \\
(2.75)\end{array}$ & & $\begin{array}{l}0.160^{* * * *} \\
(4.06)\end{array}$ & & $\begin{array}{l}0.039^{* *} \\
(2.12)\end{array}$ & & $\begin{array}{l}0.052^{* * * *} \\
(3.16)\end{array}$ \\
\hline TUncertainty & $\begin{array}{l}-0.001 \\
(0.90)\end{array}$ & & $\begin{array}{l}-1.280^{* * *} \\
(8.42)\end{array}$ & & $\begin{array}{l}-0.445^{* * *} \\
(6.38)\end{array}$ & & $\begin{array}{l}-0.434 * * * \\
(6.89)\end{array}$ & \\
\hline TCertainty & & $\begin{array}{l}0.000^{*} \\
(1.77)\end{array}$ & & $\begin{array}{l}0.043^{* * *} \\
(11.88)\end{array}$ & & $\begin{array}{l}0.016^{* * *} \\
(9.57)\end{array}$ & & $\begin{array}{l}0.014 * * * \\
(9.48)\end{array}$ \\
\hline NetNegMgt & $\begin{array}{l}-0.000 \\
(0.19)\end{array}$ & & $\begin{array}{l}-0.071 \\
(1.06)\end{array}$ & & $\begin{array}{l}-0.067 * * \\
(2.27)\end{array}$ & & $\begin{array}{l}-0.056^{* *} \\
(2.02)\end{array}$ & \\
\hline NetPessMgt & & $\begin{array}{l}-0.000 \\
(1.21)\end{array}$ & & $\begin{array}{l}-0.107 * * \\
(2.55)\end{array}$ & & $\begin{array}{l}-0.057 * * * \\
(3.02)\end{array}$ & & $\begin{array}{l}-0.046^{* * *} \\
(2.71)\end{array}$ \\
\hline TUncMgt & $\begin{array}{l}0.001 \\
(1.17)\end{array}$ & & $\begin{array}{l}0.022 \\
(0.15)\end{array}$ & & $\begin{array}{l}0.001 \\
(0.02)\end{array}$ & & $\begin{array}{l}0.010 \\
(0.17)\end{array}$ & \\
\hline
\end{tabular}


Table 6 - Regression of 5-hour Intraday Market Response on Call Sentiment (continued)

\begin{tabular}{|c|c|c|c|c|c|c|c|c|}
\hline & AbnRet & AbnRet & Intraday $V$ & Intraday V & AbnPrange & AbnPrange & AbnPstd & AbnPstd \\
\hline TCerMgt & & $\begin{array}{l}-0.000 \\
(1.35)\end{array}$ & & $\begin{array}{l}0.023 * * * \\
(5.07)\end{array}$ & & $\begin{array}{l}0.009^{* * * *} \\
(4.67)\end{array}$ & & $\begin{array}{l}0.008 * * * \\
(4.38)\end{array}$ \\
\hline $\log T A$ & $\begin{array}{l}0.000^{* *} \\
(2.57)\end{array}$ & $\begin{array}{l}0.000^{*} \\
(1.77)\end{array}$ & $\begin{array}{l}-0.258^{* * * *} \\
(12.24)\end{array}$ & $\begin{array}{l}-0.344^{* * *} \\
(15.41)\end{array}$ & $\begin{array}{l}-0.023 * * \\
(2.48)\end{array}$ & $\begin{array}{l}-0.058^{* * * *} \\
(6.06)\end{array}$ & $\begin{array}{l}-0.021 * * * \\
(2.58)\end{array}$ & $\begin{array}{l}-0.051^{* * * *} \\
(5.96)\end{array}$ \\
\hline $\log M B$ & $\begin{array}{l}-0.002 * * \\
(3.80)\end{array}$ & $\begin{array}{l}*-0.002 * * \\
(3.80)\end{array}$ & $\begin{array}{l}0.017 \\
(0.22)\end{array}$ & $\begin{array}{l}-0.073 \\
(0.93)\end{array}$ & $\begin{array}{l}0.052 \\
(1.64)\end{array}$ & $\begin{array}{l}0.014 \\
(0.42)\end{array}$ & $\begin{array}{l}0.039 \\
(1.38)\end{array}$ & $\begin{array}{l}0.008 \\
(0.29)\end{array}$ \\
\hline EarnGrowth1 & $\begin{array}{l}0.001 \\
(0.38)\end{array}$ & $\begin{array}{l}0.001 \\
(0.40)\end{array}$ & $\begin{array}{l}0.558^{*} \\
(1.92)\end{array}$ & $\begin{array}{l}0.583^{* *} \\
(2.04)\end{array}$ & $\begin{array}{l}0.123 \\
(0.89)\end{array}$ & $\begin{array}{l}0.134 \\
(0.98)\end{array}$ & $\begin{array}{l}-0.005 \\
(0.03)\end{array}$ & $\begin{array}{l}0.003 \\
(0.02)\end{array}$ \\
\hline EarnGrowth2 & $\begin{array}{l}-0.007^{*} \\
(1.81)\end{array}$ & $\begin{array}{l}-0.007^{*} \\
(1.83)\end{array}$ & $\begin{array}{l}-0.314 \\
(1.16)\end{array}$ & $\begin{array}{l}-0.234 \\
(0.88)\end{array}$ & $\begin{array}{l}-0.136 \\
(1.08)\end{array}$ & $\begin{array}{l}-0.106 \\
(0.85)\end{array}$ & $\begin{array}{l}-0.145 \\
(1.27)\end{array}$ & $\begin{array}{l}-0.118 \\
(1.05)\end{array}$ \\
\hline EarnGrowth3 & $\begin{array}{l}0.005 \\
(1.35)\end{array}$ & $\begin{array}{l}0.005 \\
(1.40)\end{array}$ & $\begin{array}{l}-0.445 \\
(1.60)\end{array}$ & $\begin{array}{l}-0.374 \\
(1.36)\end{array}$ & $\begin{array}{l}-0.120 \\
(0.88)\end{array}$ & $\begin{array}{l}-0.093 \\
(0.69)\end{array}$ & $\begin{array}{l}-0.030 \\
(0.25)\end{array}$ & $\begin{array}{l}-0.008 \\
(0.06)\end{array}$ \\
\hline Industry Dummies & Yes & Yes & Yes & Yes & Yes & Yes & Yes & Yes \\
\hline FiscalQtr Dummies & Yes & Yes & Yes & Yes & Yes & Yes & Yes & Yes \\
\hline Year Dummies & Yes & Yes & Yes & Yes & Yes & Yes & Yes & Yes \\
\hline $\begin{array}{l}\text { Std. Errors } \\
\text { Clustered by Firm }\end{array}$ & Yes & Yes & Yes & Yes & Yes & Yes & Yes & Yes \\
\hline$N$ & 21,728 & 21,728 & 21,728 & 21,728 & 21,724 & 21,724 & 21,713 & 21,713 \\
\hline$R$-square & 0.009 & 0.009 & 0.066 & 0.078 & 0.037 & 0.045 & 0.031 & 0.038 \\
\hline
\end{tabular}


Table 7 - Determinants of the Time of the Call

\begin{tabular}{|c|c|c|c|c|c|c|}
\hline \multirow{2}{*}{ Intercept } & \multicolumn{6}{|c|}{ Afternoon $=1$} \\
\hline & $\begin{array}{l}-0.863^{* * *} \\
(3.16)\end{array}$ & $\begin{array}{l}-2.890^{* * *} \\
(13.65)\end{array}$ & $\begin{array}{l}-0.984 * * * \\
(3.71)\end{array}$ & $\begin{array}{l}-3.005^{* * *} \\
(14.68)\end{array}$ & $\begin{array}{l}-0.920^{* * *} \\
(2.95)\end{array}$ & $\begin{array}{l}-2.821 * * * \\
(12.23)\end{array}$ \\
\hline HiTec & $\begin{array}{l}0.298^{* *} \\
(1.98)\end{array}$ & $\begin{array}{l}0.002 \\
(0.01)\end{array}$ & $\begin{array}{l}0.323^{* *} \\
(2.17)\end{array}$ & $\begin{array}{l}0.016 \\
(0.15)\end{array}$ & $\begin{array}{l}0.319^{* *} \\
(2.16)\end{array}$ & $\begin{array}{l}0.033 \\
(0.30)\end{array}$ \\
\hline absSUE & $\begin{array}{l}0.028 \\
(0.97)\end{array}$ & $\begin{array}{l}0.001 \\
(0.03)\end{array}$ & $\begin{array}{l}0.034 \\
(1.23)\end{array}$ & $\begin{array}{l}0.013 \\
(0.36)\end{array}$ & $\begin{array}{l}0.033 \\
(1.20)\end{array}$ & $\begin{array}{l}0.015 \\
(0.41)\end{array}$ \\
\hline$B A D$ & $\begin{array}{l}0.106^{*} \\
(1.82)\end{array}$ & $\begin{array}{l}-0.025 \\
(0.35)\end{array}$ & $\begin{array}{l}0.113^{* *} \\
(1.98)\end{array}$ & $\begin{array}{l}-0.004 \\
(0.06)\end{array}$ & $\begin{array}{l}0.112^{*} \\
(1.95)\end{array}$ & $\begin{array}{l}-0.009 \\
(0.13)\end{array}$ \\
\hline $\log T A$ & $\begin{array}{l}-0.122 * * * \\
(2.86)\end{array}$ & $\begin{array}{l}-0.060^{* *} \\
(2.09)\end{array}$ & $\begin{array}{l}-0.102 * * \\
(2.43)\end{array}$ & $\begin{array}{l}-0.047^{*} \\
(1.68)\end{array}$ & $\begin{array}{l}-0.114^{* * *} \\
(2.63)\end{array}$ & $\begin{array}{l}-0.065^{* *} \\
(2.21)\end{array}$ \\
\hline $\log A n a$ & $\begin{array}{l}-0.019 \\
(0.18)\end{array}$ & $\begin{array}{l}-0.035 \\
(0.51)\end{array}$ & $\begin{array}{l}-0.029 \\
(0.30)\end{array}$ & $\begin{array}{l}-0.037 \\
(0.56)\end{array}$ & $\begin{array}{l}-0.021 \\
(0.21)\end{array}$ & $\begin{array}{l}-0.017 \\
(0.25)\end{array}$ \\
\hline lag_Afternoon & & $\begin{array}{l}4.486^{* * * *} \\
(43.44)\end{array}$ & & $\begin{array}{l}4.484 * * * \\
(44.15)\end{array}$ & & $\begin{array}{l}4.505^{* * *} \\
(44.26)\end{array}$ \\
\hline FQ4 & $\begin{array}{l}0.030 \\
(1.12)\end{array}$ & $\begin{array}{l}0.100 \\
(1.28)\end{array}$ & $\begin{array}{l}0.017 \\
(0.64)\end{array}$ & $\begin{array}{l}0.082 \\
(1.09)\end{array}$ & $\begin{array}{l}0.010 \\
(0.38)\end{array}$ & $\begin{array}{l}0.078 \\
(1.03)\end{array}$ \\
\hline EquiDepend1 & $\begin{array}{l}-0.004 \\
(0.55)\end{array}$ & $\begin{array}{l}-0.005 \\
(0.99)\end{array}$ & & & & \\
\hline EquiDepend2 & & & $\begin{array}{l}0.002 \\
(0.39)\end{array}$ & $\begin{array}{l}-0.001 \\
(0.25)\end{array}$ & & \\
\hline InvestIntense & & & & & $\begin{array}{l}0.029 \\
(0.09)\end{array}$ & $\begin{array}{l}-0.295 \\
(1.14)\end{array}$ \\
\hline Year Dummies & Yes & Yes & Yes & Yes & Yes & Yes \\
\hline $\begin{array}{l}\text { Std. Errors } \\
\text { Clustered by Firm }\end{array}$ & Yes & Yes & Yes & Yes & Yes & Yes \\
\hline$N$ & 21,747 & 20,426 & 22,874 & 21,478 & 22,699 & 21,316 \\
\hline Pseudo R-square & 0.013 & 0.510 & 0.011 & 0.509 & 0.012 & 0.512 \\
\hline
\end{tabular}


Table 8 - Afternoon Timing of the Calls and Returns Patterns over Various Intervals

\begin{tabular}{|c|c|c|c|c|c|c|c|c|}
\hline \multirow[b]{3}{*}{ Intercept } & \multirow{2}{*}{\multicolumn{2}{|c|}{ 5-hours }} & \multicolumn{4}{|c|}{ Post-Call Period } & \multirow{2}{*}{\multicolumn{2}{|c|}{$\begin{array}{c}\text { Full Period } \\
{[0,50]}\end{array}$}} \\
\hline & & & \multicolumn{2}{|c|}{$[1,15]$} & \multicolumn{2}{|c|}{$[16,50]$} & & \\
\hline & $\begin{array}{l}-0.000 \\
(0.19)\end{array}$ & $\begin{array}{l}-0.003^{*} \\
(1.83)\end{array}$ & $\begin{array}{l}0.020 * * * \\
(5.35)\end{array}$ & $\begin{array}{l}0.016 * * * \\
(4.19)\end{array}$ & $\begin{array}{l}0.010^{*} \\
(1.81)\end{array}$ & $\begin{array}{l}0.008 \\
(1.42)\end{array}$ & $\begin{array}{l}0.052 * * * \\
(6.77)\end{array}$ & $\begin{array}{l}0.034 * * * \\
(4.46)\end{array}$ \\
\hline SUE & $\begin{array}{l}0.003 * * * \\
(6.84)\end{array}$ & $\begin{array}{l}0.003^{* * *} \\
(6.90)\end{array}$ & $\begin{array}{l}0.006^{* * * *} \\
(7.79)\end{array}$ & $\begin{array}{l}0.006^{* * *} \\
(7.94)\end{array}$ & $\begin{array}{l}0.006^{* * * *} \\
(6.01)\end{array}$ & $\begin{array}{l}0.006^{* * *} \\
(6.07)\end{array}$ & $\begin{array}{l}0.031 * * * \\
(18.76)\end{array}$ & $\begin{array}{l}0.031 * * * \\
(18.95)\end{array}$ \\
\hline$B A D$ & $\begin{array}{l}-0.002 * * * \\
(2.91)\end{array}$ & $\begin{array}{l}-0.002^{* * * *} \\
(2.79)\end{array}$ & $\begin{array}{l}-0.004 * * \\
(2.00)\end{array}$ & $\begin{array}{l}-0.004 * * \\
(2.03)\end{array}$ & $\begin{array}{l}0.006^{* *} \\
(1.99)\end{array}$ & $\begin{array}{l}0.006^{* * *} \\
(1.97)\end{array}$ & $\begin{array}{l}-0.016^{* * * *} \\
(4.21)\end{array}$ & $\begin{array}{l}-0.016^{* * *} \\
(4.17)\end{array}$ \\
\hline SUEXBAD & $\begin{array}{l}-0.003 * * * \\
(3.91)\end{array}$ & $\begin{array}{l}-0.003 * * * \\
(3.96)\end{array}$ & $\begin{array}{l}-0.005^{* * * *} \\
(2.83)\end{array}$ & $\begin{array}{l}-0.005 * * * \\
(2.83)\end{array}$ & $\begin{array}{l}-0.007 * * * \\
(2.73)\end{array}$ & $\begin{array}{l}-0.007 * * * \\
(2.72)\end{array}$ & $\begin{array}{l}-0.022 * * * \\
(6.50)\end{array}$ & $\begin{array}{l}-0.022 * * * \\
(6.50)\end{array}$ \\
\hline Afternoon & $\begin{array}{l}-0.001 \\
(1.06)\end{array}$ & $\begin{array}{l}-0.001 \\
(1.10)\end{array}$ & $\begin{array}{l}-0.003 * * \\
(2.09)\end{array}$ & $\begin{array}{l}-0.003 * * \\
(2.22)\end{array}$ & $\begin{array}{l}0.004 * \\
(1.86)\end{array}$ & $\begin{array}{l}0.004^{*} \\
(1.83)\end{array}$ & $\begin{array}{l}0.000 \\
(0.11)\end{array}$ & $\begin{array}{l}-0.000 \\
(0.02)\end{array}$ \\
\hline NetNegativity & $\begin{array}{l}-0.003 * * * \\
(3.67)\end{array}$ & & $\begin{array}{l}-0.006^{* * * *} \\
(2.88)\end{array}$ & & $\begin{array}{l}-0.002 \\
(0.80)\end{array}$ & & $\begin{array}{l}-0.020^{* * * *} \\
(5.18)\end{array}$ & \\
\hline NetPessimism & & $\begin{array}{l}-0.001 * * \\
(2.29)\end{array}$ & & $\begin{array}{l}0.000 \\
(0.54)\end{array}$ & & $\begin{array}{l}-0.000 \\
(0.20)\end{array}$ & & $\begin{array}{l}-0.004^{* *} \\
(2.47)\end{array}$ \\
\hline NetNegMgt & $\begin{array}{l}0.000 \\
(0.10)\end{array}$ & & $\begin{array}{l}-0.002^{*} \\
(1.67)\end{array}$ & & $\begin{array}{l}-0.002 \\
(0.85)\end{array}$ & & $\begin{array}{l}-0.006 * * \\
(2.54)\end{array}$ & \\
\hline NetPessMgt & & $\begin{array}{l}-0.001 \\
(1.55)\end{array}$ & & $\begin{array}{l}-0.002 * * * \\
(3.03)\end{array}$ & & $\begin{array}{l}-0.001 \\
(0.69)\end{array}$ & & $\begin{array}{l}-0.004 * * * \\
(3.04)\end{array}$ \\
\hline $\log T A$ & $\begin{array}{l}0.000 * * \\
(2.47)\end{array}$ & $\begin{array}{l}0.000 * * \\
(2.05)\end{array}$ & $\begin{array}{l}-0.001 * * \\
(2.28)\end{array}$ & $\begin{array}{l}-0.001 * * * \\
(2.82)\end{array}$ & $\begin{array}{l}-0.002 * * * \\
(3.66)\end{array}$ & $\begin{array}{l}-0.002 * * * \\
(3.75)\end{array}$ & $\begin{array}{l}-0.003 * * * \\
(4.64)\end{array}$ & $\begin{array}{l}-0.003^{* * * *} \\
(5.28)\end{array}$ \\
\hline $\log M B$ & $\begin{array}{l}-0.002 * * * \\
(3.78)\end{array}$ & $\begin{array}{l}-0.002 * * * \\
(3.73)\end{array}$ & $\begin{array}{l}-0.011 * * * \\
(8.20)\end{array}$ & $\begin{array}{l}-0.011 * * * \\
(8.04)\end{array}$ & $\begin{array}{l}-0.009 * * * \\
(4.53)\end{array}$ & $\begin{array}{l}-0.009 * * * \\
(4.43)\end{array}$ & $\begin{array}{l}-0.031 * * * \\
(10.58)\end{array}$ & $\begin{array}{l}-0.030 * * * \\
(10.27)\end{array}$ \\
\hline EarnGrowth1 & $\begin{array}{l}0.001 \\
(0.36) \\
\end{array}$ & $\begin{array}{l}0.001 \\
(0.36) \\
\end{array}$ & $\begin{array}{l}0.007 \\
(0.67) \\
\end{array}$ & $\begin{array}{l}0.007 \\
(0.72)\end{array}$ & $\begin{array}{l}0.068^{* * * *} \\
(4.76)\end{array}$ & $\begin{array}{l}0.068 * * * \\
(4.78)\end{array}$ & $\begin{array}{l}0.095 * * * \\
(4.57)\end{array}$ & $\begin{array}{l}0.096^{* * *} \\
(4.64)\end{array}$ \\
\hline
\end{tabular}


Table 8 - Afternoon Timing of the Calls and Returns Patterns over Various Intervals (continued)

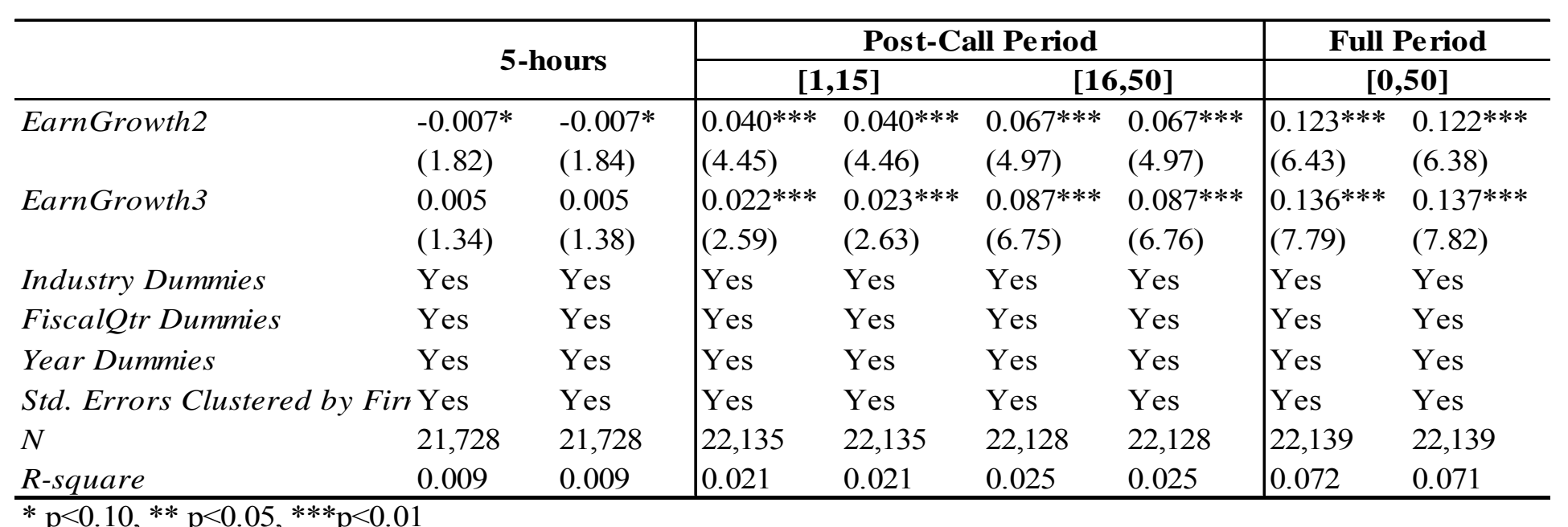

